\title{
Review \\ The Pleiotropic Potential of BDNF beyond Neurons: Implication for a Healthy Mind in a Healthy Body
}

\author{
Maria Carmela Di Rosa ${ }^{1,2,+}$ (D), Stefania Zimbone ${ }^{2,+}$, Miriam Wissam Saab ${ }^{1}$ and Marianna Flora Tomasello ${ }^{2, *(D)}$ \\ 1 Department of Biomedical and Biotechnological Sciences, University of Catania, Via S. Sofia 64, \\ 95123 Catania, Italy; mcdirosa@unict.it (M.C.D.R.); mirisaab@gmail.com (M.W.S.) \\ 2 Institute of Crystallography, CNR, Via P. Gaifami 18, 95126 Catania, Italy; stefania_zimbone@libero.it \\ * Correspondence: mariannaflora.tomasello@cnr.it \\ + These authors have equally contributed.
}

check for updates

Citation: Di Rosa, M.C.; Zimbone, S.; Saab, M.W.; Tomasello, M.F. The Pleiotropic Potential of BDNF beyond Neurons: Implication for a Healthy Mind in a Healthy Body. Life 2021, 11, 1256. https://doi.org/10.3390/ life11111256

Academic Editor: Vsevolod Pinelis

Received: 29 September 2021 Accepted: 15 November 2021 Published: 17 November 2021

Publisher's Note: MDPI stays neutral with regard to jurisdictional claims in published maps and institutional affiliations.

Copyright: (c) 2021 by the authors. Licensee MDPI, Basel, Switzerland. This article is an open access article distributed under the terms and conditions of the Creative Commons Attribution (CC BY) license (https:// creativecommons.org/licenses/by/ $4.0 /)$.

\begin{abstract}
Brain-derived neurotrophic factor (BDNF) represents one of the most widely studied neurotrophins because of the many mechanisms in which it is involved. Among these, a growing body of evidence indicates BDNF as a pleiotropic signaling molecule and unveils non-negligible implications in the regulation of energy balance. BDNF and its receptor are extensively expressed in the hypothalamus, regions where peripheral signals, associated with feeding control and metabolism activation, and are integrated to elaborate anorexigenic and orexigenic effects. Thus, BDNF coordinates adaptive responses to fluctuations in energy intake and expenditure, connecting the central nervous system with peripheral tissues, including muscle, liver, and the adipose tissue in a complex operational network. This review discusses the latest literature dealing with the involvement of BDNF in the maintenance of energy balance. We have focused on the physiological and molecular mechanisms by which BDNF: (I) controls the mitochondrial function and dynamics; (II) influences thermogenesis and tissue differentiation; (III) mediates the effects of exercise on cognitive functions; and (IV) modulates insulin sensitivity and glucose transport at the cellular level. Deepening the understanding of the mechanisms exploited to maintain energy homeostasis will lay the groundwork for the development of novel therapeutical approaches to help people to maintain a healthy mind in a healthy body.
\end{abstract}

Keywords: BDNF; hypothalamus; mitochondria; exercise; metabolism; energy balance; pleiotropic; neurons

\section{Introduction}

Brain-derived neurotrophic factor (BDNF) is a member of the neurotrophin family along with the nerve growth factor (NGF), neurotrophin 3 (NT-3) and neurotrophin 4 (NT-4) [1]. BDNF is critically involved in neuronal development and synaptic plasticity; it promotes neuronal differentiation stimulating neurite outgrowth and synapses formation, and can prevent apoptosis [2].

For the crucial and physiological functions performed, the gene structure of BDNF is highly conserved throughout mammals and its transcription is tightly regulated and cell-type specific [1].

BDNF and its high-affinity receptor TrkB (tropomyosin-related kinase B) are widely expressed in the developing and mature central nervous system (CNS) and in many peripheral tissues, including muscle, liver and adipose tissue [3].

BDNF is synthesized as pro-BDNF and converted into mature BDNF (mBDNF) by furin and proconvertases within intracellular vesicles. Neurons are able to release either mBDNF or pro-BDNF in response to numerous stimuli. The ratio between pro-BDNF and mBDNF changes during distinct developmental stages and postnatal life $[1,4-6]$. When released, pro-BDNF is converted by the tissue plasminogen activator/plasmin system into $\mathrm{mBDNF}$ or may act as an independent ligand preferentially on the neurotrophin receptor p75 (p75 $\left.{ }^{\mathrm{NTR}}\right)$, a member of the tumor necrosis factor family of receptors. Although with a 
much lower affinity, mBDNF is also able to bind the $\mathrm{p} 75^{\mathrm{NTR}}$. Notably, TrkB and $\mathrm{p} 75^{\mathrm{NTR}}$ seem to mediate functionally antagonistic actions $[1,2,7]$.

Once released, $\mathrm{mBDNF}$ forms stable homodimers and exerts its action locally, since the biochemical characteristics prevent the broad diffusion of the neurotrophin [1]. The binding of $\mathrm{mBDNF}$ to TrkB induces receptor dimerization and the autophosphorylation of tyrosine residues in the intracellular domain, which triggers a complex set of signaling cascades, specifically the tissue phospholipase C (PLC), phosphatidylinositol-3 kinase (PI3-K) and MAPK pathways. This results in the activation of specific transcriptional factors which in turn control the expression of proteins involved in plasticity, neuronal survival, cellular energy balance and mitochondrial biogenesis. BDNF also upregulates antioxidant proteins, modulates cytoskeletal dynamism and prevents apoptosis by promoting the expression of the anti-apoptotic Bcl-2 family members and inhibiting the pro-apoptotic ones [2,8].

This review deals with the intriguing topic of the BDNF involvement in energy homeostasis. In particular, we will discuss the most recent findings and theories hinting at a role for BDNF as a homeostatic factor regulating energy intake and expenditure in both the CNS and the peripheral metabolic organs.

\section{The Role of BDNF in the Central Control of Energy Balance}

Energy homeostasis is the result of a complex interplay between the brain and peripheral tissues. Neuronal circuitry in the hypothalamus and hindbrain receives and integrates peripheral signals related to hunger, satiety and energy storage in the body and elaborate specific responses regulating nutrient intake and energy expenditure. Therefore, to maintain energy balance, organisms have to evaluate changes in energy needs considering several factors such as physical activity and thermoregulation. Hormones such as insulin, leptin, PYY and ghrelin, allow this tightly regulated information exchange [9-11]. Alongside hormones, emerging players in the energy balance regulation are neurotrophins, most notably, BDNF and its receptor, both abundantly expressed in several regions of hypothalamus and hindbrain $[3,12]$.

The involvement of BDNF in the central regulation of feeding was noticed earlier during investigations aiming at improving the knowledge about how BDNF regulates learning, memory, synaptic transmission and plasticity [11]. The intracerebroventricular (ICV) injection of BDNF in rats to evaluate the neurotrophic effect in the treatment of Alzheimer's also induced appetite suppression and weight loss $[13,14]$. In mice models of diabetes and obesity, BDNF administration produced anorexigenic effects, reduced blood glucose and increased pancreatic insulin content $[15,16]$. These data were also confirmed in BDNF heterozygous mice in which about half of them exhibited a hyperphagic obesity; notably, chronic brain infusion of BDNF in obese BDNF-deficient mice was able to transiently reduce body weight [17]. BDNF involvement in the regulation of energy homeostasis was also reported in humans, in a young patient characterized by the early onset of obesity and hyperphagia along with developmental delays and other neurological defects. The young patient carried a heterozygous mutation in the NTRK2 gene, which encodes for the TrkB receptor. Namely, the mutation impinges on the activation loop of the TrkB catalytic domain (Y722C) leading to the loss of TrkB function [11,18]. Furthermore, mutations in the gene encoding BDNF are associated with eating disorders inducing obesity, hyperactivity as well as impaired cognitive functions. These data link BDNF to the regulation of energy homeostasis in humans [19-21] (Box 1 and Table 1). 
Box 1. Genetic studies in humans carrying BDNF mutations.

Genetic disorders causing BDNF haploinsufficiency or TrkB inactivation provide direct evidence for the understanding of the role of BDNF in the regulation of energy balance in humans. A deficit in BDNF expression or in its signalling may contribute to weight gain and cognitive impairment which vary in phenotypic severity $[22,23]$.

Gray et al. identified a chromosomal inversion encompassing BDNF gene in an 8-year-old girl with hyperphagia, severe obesity, hyperactivity and cognitive impairment. The chromosomal inversion affected BDNF expression with a loss of function without disrupting the sequence of the gene itself [19]. An additional study reported a BDNF haploinsufficiency in a cohort of patients with WAGR syndrome, a rare genetic disorder caused by contiguous gene deletions on chromosome $11 \mathrm{p} 13$ region of varying size. Since the BDNF gene is located in the chromosomal locus 11p14.1, approximately half of the patients with WAGR syndrome had a heterozygous BDNF deletion. In these subjects, BDNF haploinsufficiency was significantly associated with a rise in body mass index, hyperphagia and reduced BDNF levels in serum along with neurocognitive impairments [20]. Similarly, low levels of serum BDNF were reported in patients with metabolic and eating disorders $[24,25]$.

Several genome-wide association studies have strengthened these findings identifying BDNF single nucleotide polymorphisms (SNPs) linked to an increased risk of developing obesity in humans. The most commonly studied BDNF SNP is the G196A variant which causes the substitution of valine with methionine in the pro-BDNF position 66 (Val66Met). The amino acid change affects the intracellular trafficking and packaging of pro-BDNF impinging the activitydependent secretion of mBDNF [22,26-28]. A rare de novo missense variant in BDNF and seven NTRK2 mutations along with three variants previously reported [23] have also been functionally characterized by Sonoyama et al. Clinical data collected from carriers of BDNF/TrkB variants showed in addition to severe obesity, a spectrum of neurobehavioral disorders such as hyperactivity, learning deficit and shot-term memory impairment [29]. Interestingly, a latest study reports an atypical Charcot-Marie-Tooth disease type $2 \mathrm{Q}$ phenotype with obesity likely related to the mutation identified in the coding region of the NTRK2 gene [30].

All things considered, there is clear evidence of the crucial role of BDNF in modulating body weight and energy homeostasis, although further studies are needed to better elucidate the BDNF involvement in these syndromes (Table 1).

Table 1. Clinical studies on common and rare variants in BDNF and NTRK2.

\begin{tabular}{|c|c|c|c|}
\hline Gene & Mutations & Phenotypic Features & Reference \\
\hline \multirow{6}{*}{ BDNF } & $\begin{array}{l}\text { 11p inversion; } \\
\text { haploinsufficiency }\end{array}$ & $\begin{array}{l}\text { Severe obesity, } \\
\text { hyperphagia, impaired } \\
\text { cognitive function, } \\
\text { hyperactivity }\end{array}$ & $\begin{array}{l}\text { [19] Gray, J. et al., } 2006 \\
\text { [22] Han, J.C., } 2016\end{array}$ \\
\hline & Deletions including the & & \\
\hline & $\begin{array}{l}\text { 11p14 BDNF locus } \\
\text { among patients with } \\
\text { WAGR syndrome; } \\
\text { haploinsufficiency }\end{array}$ & $\begin{array}{l}\text { Obesity, hyperphagia, } \\
\text { lower levels of serum } \\
\text { BDNF }\end{array}$ & $\begin{array}{l}\text { [20] Han, J.C. et al., } 2008 \\
\text { [22] Han, J.C., } 2016\end{array}$ \\
\hline & $\begin{array}{l}\text { Intronic SNP: rs12291063 } \\
\text { CC genotype }\end{array}$ & Obesity & [21] Mou, Z. et al., 2015 \\
\hline & $\begin{array}{c}\text { SNP rs6265 commonly } \\
\text { known as G196A => } \\
\text { Val66Met }\end{array}$ & $\begin{array}{l}\text { Susceptibility to obesity, } \\
\text { several psychiatric } \\
\text { conditions including } \\
\text { eating disorders }\end{array}$ & $\begin{array}{c}\text { [25] Rosas-Vargas, H. et al., } \\
\text { 2011 } \\
\text { [26] Vidović, V. et al., } 2020 \\
\text { [27] Ieraci, A. et al., } 2020 \\
\text { [22] Han, J.C., 2016 }\end{array}$ \\
\hline & $\begin{array}{l}\text { Missense mutation } \\
\text { E183K }\end{array}$ & $\begin{array}{c}\text { Severe obesity and } \\
\text { moderately learning } \\
\text { difficulties }\end{array}$ & $\begin{array}{l}\text { [29] Sonoyama, T. et al., } \\
2020\end{array}$ \\
\hline \multirow{3}{*}{ NTRK2 } & $\begin{array}{l}\text { Missense mutation } \\
\text { Y722C }\end{array}$ & $\begin{array}{l}\text { Severe early-onset } \\
\text { obesity, hyperphagia, } \\
\text { developmental delay }\end{array}$ & [18] Yeo, G.S.H. et al., 2004 \\
\hline & $\begin{array}{l}\text { Missense mutations: } \\
\text { I98V, P660L, T821A }\end{array}$ & $\begin{array}{c}\text { Severe obesity, } \\
\text { developmental delay }\end{array}$ & [23] Gray, J. et al., 2007 \\
\hline & $\begin{array}{c}\text { Missense mutations: } \\
\text { P204H, R691H, R696K, } \\
\text { S714F, R715Q, } \\
\text { R715W, P831L }\end{array}$ & $\begin{array}{c}\text { Severe obesity, } \\
\text { hyperactivity, } \\
\text { maladaptive behaviours } \\
\text { and impaired } \\
\text { short-term memory }\end{array}$ & $\begin{array}{l}\text { [29] Sonoyama, T. et al., } \\
2020\end{array}$ \\
\hline
\end{tabular}


In the hypothalamus, BDNF is synthesized in several regions participating in metabolic homeostasis, including the ventromedial hypothalamic nucleus $(\mathrm{VMH})$, the dorsomedial hypothalamic nucleus (DMH), the paraventricular nucleus $(\mathrm{PVH})$ and the lateral hypothalamic area (LH). The arcuate nucleus (ARC), a crucial hypothalamic center controlling energy balance, does not seem to be involved in BDNF synthesis but in its function [3,11]. In fact, TrkB is expressed in the ARC, which in turn, displays two functionally different populations of neurons: (i) cells producing the anorexigenic polypeptides cocaineand amphetamine-regulated transcript (CART) and proopiomelanocortin (POMC), a precursor of $\alpha$-melanocyte stimulating hormone ( $\alpha$-MSH), the ligand of melanocortin receptor 4 (MC4R), and (ii) cells producing the orexigenic neuropeptide Y (NPY) and the agouti-related protein (AgRP), an antagonist of MC4R [10,12]. Metabolic and nutritional signals mediated by peripheral factors are integrated in this region which is connected to other hypothalamic nuclei crucial in the control of feeding. Notably, BDNF seems to be essential in promoting axonal projections of TrkB expressing neurons from ARC to the $\mathrm{PVH}$ and DMH [31]. An earlier study also showed a link between the local translation of BDNF in hypothalamic neuronal dendrites and the activity of leptin and anorexigenic hormone released by adipose tissue [32,33].

The VMH represents the principal region where BDNF is produced in response to finely tuned stimuli integrated from nutritional cues such as glucose, leptin or fasting. Unger and collaborators demonstrated that glucose administration in adult mice induced an increase in both BDNF and TrkB levels in VMH and that the deletion of the BDNF gene in the $\mathrm{VMH}$ and $\mathrm{DMH}$ produced hyperphagic obesity without changing energy output and locomotion. Thus, the VMH and DMH have been pinpointed as important sources of BDNF for the regulation of satiety and appetite suppression [34]. It was also shown that BDNF expression in VMH is upregulated in response to leptin [35] and modulated by MC4R signaling [36]. In particular, the evidence that: (i) a MC4R agonist largely raised BDNF mRNA levels in the VMH following a period of food deprivation and (ii) the brain infusion of BDNF restored a normal feeding behavior in mice deficient of MC4R signaling and fed with a high-fat diet (HFD) suggested the presence of circuitry in which BDNF represents a downstream effector of MC4R signaling [36,37]. To date, the mechanism regulating the synthesis of BDNF is still unclear. BDNF expression could be directly mediated by specific cues, as described above, and/or indirectly triggered via the action of relevant stimuli acting on circuits connecting hypothalamic nuclei each other [11,35].

Similar results were achieved in the dorsal vagal complex (DVC) of the hindbrain. Studies in adult rats provide evidence that BDNF delivery in the DVC negatively regulates food intake and that BDNF/TrkB signaling could mediate the action of melanocortins and could contribute to the leptin anorexic effect [38-40].

The key role of BDNF in regulating energy balance was also investigated in the $\mathrm{PVH}$. In particular, the injection of BDNF in this region caused a loss of body weight in rats by reducing food intake and promoting energy expenditure as a consequence of an increased resting metabolite rate, likely associated with the thermogenic effect of the uncoupling protein 1 (UCP1) in the brown adipose tissue (BAT) [41,42]. Alongside the regulation of food intake, the involvement of BDNF in energy expenditure may also be mediated through the control of BAT thermogenesis and locomotor activity. In particular, by assessing the effect of the BDNF ablation in the PVH, An et al. revealed the presence of discrete neuronal populations associated with different functions, for example, BDNF neurons in the anterior $\mathrm{PVH}$ related to hyperphagia and reduced locomotor activity and BDNF neurons in medial and posterior $\mathrm{PVH}$ promoting thermogenesis through polysynaptic connections with the BAT [43]. In a follow-up study, the same authors, using a projection-specific gene deletion approach, accurately investigated the action site of PVH neurons expressing TrkB and identified neuronal networks with the VMH and lateral parabrachial nucleus (LPBN) involved in appetite suppression [44].Energy consumption mediated by thermogenesis and physical activity was furthermore induced by the activation of neurons that express TrkB in the DMH. This recent study revealed distinct neuronal populations expressing 
TrkB which create neurocircuitry by projections to several brain regions (raphe pallidus, $\mathrm{PVH}$ and preoptic area) to accurately manage energy expenditure and food intake [45]. The more significant studies investigating the role and the effects of BDNF in the central control of energy balance are summarized below (Table 2).

Table 2. The more significant studies investigating the role and the effects of BDNF in the central control of energy balance in rodents' models.

\begin{tabular}{|c|c|c|c|}
\hline Animal Model & Intervention/Stimuli & Effects & Reference \\
\hline Wistar rats & $\begin{array}{l}\text { Chronic } \\
\text { intraventricular } \\
\text { administration of } \\
\text { BDNF and NGF }\end{array}$ & $\begin{array}{l}\text { Reduction in } \\
\text { weight gain }\end{array}$ & $\begin{array}{l}\text { [13] Lapchak, P.A.; } \\
\text { Hefti, F., } 1992\end{array}$ \\
\hline Long-Evans rats & $\begin{array}{l}\text { ICV BDNF infusion } \\
\text { (lateral ventricle) }\end{array}$ & $\begin{array}{l}\text { Appetite suppression } \\
\text { and weight loss }\end{array}$ & $\begin{array}{l}\text { [14] Pelleymounter, } \\
\text { M.A et al., } 1995\end{array}$ \\
\hline $\begin{array}{l}\text { C57BL/KsJ-db/db } \\
\text { mice } \\
\text { (obese diabetic mice) }\end{array}$ & $\begin{array}{l}\text { BDNF central (ICV) } \\
\text { administration }\end{array}$ & $\begin{array}{l}\text { Reduction in blood } \\
\text { glucose and increase } \\
\text { in pancreatic insulin }\end{array}$ & $\begin{array}{l}\text { [15] Nonomura, } \\
\text { T. et al., } 2001\end{array}$ \\
\hline $\begin{array}{c}\text { C57BL/KsJ-db/db } \\
\text { mice (obese diabetic } \\
\text { mice); } \\
\text { streptozotocin- } \\
\text { induced type } 1 \\
\text { diabetic mice; } \\
\text { KK mice } \\
\text { (normoglycemic } \\
\text { obese mice with } \\
\text { impaired glucose } \\
\text { tolerance) }\end{array}$ & $\begin{array}{l}\text { BDNF central (ICV) } \\
\text { and subcutaneous } \\
\text { administration }\end{array}$ & Antidiabetic effects & $\begin{array}{l}\text { [16] Nakagawa, } \\
\text { T. et al., } 2000\end{array}$ \\
\hline $\begin{array}{l}\text { BDNF mutant mice } \\
\text { (obese BDNF } \\
\text { heterozygous mice) }\end{array}$ & $\begin{array}{c}\text { BDNF central } \\
\text { administration (third } \\
\text { ventricle) }\end{array}$ & $\begin{array}{c}\text { Transient reversion of } \\
\text { eating behaviour and } \\
\text { obesity }\end{array}$ & $\begin{array}{l}\text { [17] Kernie, S.G. et al., } \\
2000\end{array}$ \\
\hline $\begin{array}{c}\text { Bdnf }{ }^{k l o x / k l o x} \text { mice } \\
\text { (deficiency in long } 3^{\prime} \\
\text { UTR Bdnf } \\
\text { mRNA/severe } \\
\text { obesity development) }\end{array}$ & $\begin{array}{l}\text { Viral expression of } \\
\text { long } 3^{\prime} \text { UTR Bdnf } \\
\text { mRNA in the } \\
\text { hypothalamus } \\
\text { (VMH) }\end{array}$ & $\begin{array}{l}\text { Complete rescue of } \\
\text { hyperphagic obesity }\end{array}$ & $\begin{array}{l}\text { [32] Liao, G.-Y. et al., } \\
2012\end{array}$ \\
\hline \multirow{2}{*}{ Wild-type mice } & $\begin{array}{l}\text { Intraperitoneal and } \\
\text { ICV administration of } \\
\text { glucose after } 48 \mathrm{~h} \\
\text { fasting period }\end{array}$ & $\begin{array}{l}\text { Increase in BDNF and } \\
\text { TrkB mRNA in VMH }\end{array}$ & \multirow{3}{*}{$\begin{array}{c}\text { [34] Unger, T.J. et al., } \\
2007\end{array}$} \\
\hline & $\begin{array}{l}\text { BDNF central } \\
\text { administration } \\
\text { (third ventricle) }\end{array}$ & $\begin{array}{l}\text { Neurons activation in } \\
\text { hypothalamic } \\
\text { appetite- } \\
\text { regulating centers }\end{array}$ & \\
\hline Bdnf ${ }^{2 \mathrm{~L} / 2 \mathrm{~L}}$ mice & $\begin{array}{l}\text { Selectively deletion } \\
\text { (viral-mediated) of } \\
\text { BDNF alleles in the } \\
\text { VMH and DMH }\end{array}$ & $\begin{array}{c}\text { Hyperphagic } \\
\text { behavior and obesity }\end{array}$ & \\
\hline C57BL/6J mice & $\begin{array}{c}\text { ICV leptin } \\
\text { administration }\end{array}$ & $\begin{array}{l}\text { Increase in BDNF } \\
\text { mRNA in the } \\
\text { dorsomedial part } \\
\text { of VMH }\end{array}$ & $\begin{array}{l}\text { [35] Komori, T. et al., } \\
2006\end{array}$ \\
\hline
\end{tabular}


Table 2. Cont.

\begin{tabular}{|c|c|c|c|}
\hline Animal Model & Intervention/Stimuli & Effects & Reference \\
\hline Wild-type mice & $\begin{array}{l}\text { Injection of a MC4R } \\
\text { agonist (MTII) into } \\
\text { the dorsal third } \\
\text { ventricle after a } 44 \mathrm{~h} \\
\text { fasting period }\end{array}$ & $\begin{array}{l}\text { Increase in BDNF } \\
\text { mRNA in the VMH }\end{array}$ & [36] Xu, B. et al., 2003 \\
\hline \multirow{2}{*}{ Wistar Han rats } & $\begin{array}{c}\text { Intraparenchymal } \\
\text { infusion of BDNF in } \\
\text { the DVC }\end{array}$ & $\begin{array}{l}\text { Anorexia and weight } \\
\text { loss }\end{array}$ & \multirow{2}{*}{$\begin{array}{l}\text { [38] Bariohay, B. et al. } \\
2005\end{array}$} \\
\hline & $\begin{array}{l}\text { Peripheral leptin } \\
\text { injection }\end{array}$ & $\begin{array}{l}\text { Increase in BDNF } \\
\text { protein content } \\
\text { within the DVC }\end{array}$ & \\
\hline \multirow{3}{*}{ Wistar Han rats } & $\begin{array}{l}\text { BDNF ICV injection } \\
\text { into the DVC } \\
\text { (4th ventricle) }\end{array}$ & $\begin{array}{l}\text { Reduction in } \\
\text { food intake }\end{array}$ & \multirow{3}{*}{$\begin{array}{l}\text { [39] Bariohay, B. et al., } \\
2009\end{array}$} \\
\hline & $\begin{array}{c}\text { ICV delivery of a } \\
\text { MC3/4R agonist } \\
\text { (MTII) into the DVC } \\
\text { (4th ventricle) }\end{array}$ & $\begin{array}{l}\text { Increase in the BDNF } \\
\text { protein content in } \\
\text { the DVC }\end{array}$ & \\
\hline & $\begin{array}{l}\text { ICV delivery of a } \\
\text { MC3/4R antagonist } \\
\text { (SHU9119) into the } \\
\text { DVC (4th ventricle) }\end{array}$ & $\begin{array}{l}\text { Decrease in the BDNF } \\
\text { protein content in } \\
\text { the DVC }\end{array}$ & \\
\hline \multirow{4}{*}{ Sprague-Dawley rats } & $\begin{array}{c}\text { ICV (4th } \\
\text { ventricle/hindbrain) } \\
\text { BDNF injection }\end{array}$ & $\begin{array}{l}\text { Reduction in } \\
\text { cumulative food } \\
\text { intake and body } \\
\text { weight; increase in } \\
\text { core temperature }\end{array}$ & \multirow{4}{*}{$\begin{array}{l}\text { [40] Spaeth, } \\
\text { A.M. et al., } 2012\end{array}$} \\
\hline & $\begin{array}{l}\text { Intraparenchymal } \\
\text { injection of BDNF } \\
\text { into the medial } \\
\text { nucleus tractus } \\
\text { solitarius (mNTS) }\end{array}$ & $\begin{array}{l}\text { Suppression of food } \\
\text { intake and } \\
\text { body weight }\end{array}$ & \\
\hline & $\begin{array}{l}\text { Intraparenchymal } \\
\text { delivery of BDNF } \\
\text { into the mNTS after } \\
\text { ANA-12 (specific } \\
\text { TrkB receptor } \\
\text { antagonist) } \\
\text { preadministration }\end{array}$ & $\begin{array}{l}\text { Inhibition of the } \\
\text { intake-suppressive } \\
\text { effect of BDNF }\end{array}$ & \\
\hline & $\begin{array}{c}\text { ICV (4th } \\
\text { ventricle/hindbrain) } \\
\text { leptin injection }\end{array}$ & $\begin{array}{l}\text { Increase in the BDNF } \\
\text { protein content } \\
\text { within the DVC tissue }\end{array}$ & \\
\hline Sprague-Dawley rats & $\begin{array}{l}\text { BDNF injection into } \\
\text { the PVH }\end{array}$ & $\begin{array}{l}\text { Decrease in feeding } \\
\text { and body weight; } \\
\text { increase in energy } \\
\text { expenditure; UCP1 } \\
\text { expression increase } \\
\text { in BAT }\end{array}$ & $\begin{array}{l}\text { [41] Wang, C. et al., } \\
2007\end{array}$ \\
\hline
\end{tabular}

\section{BDNF in Energy Expenditure}

As introduced in the previous paragraph, BDNF plays a key role in the management of energy balance, a tightly regulated equilibrium between energy intake and expenditure. In an organism, the total energy expenditure (TEE) has as a major component in the 
basal metabolic rate $(70 \%)$, which is the energy employed for the physiological operation of cells and organs under resting conditions. The energy expended in physical activity represents $20 \%$ of TEE and includes both volitional activity (such as exercise) and nonvolitional activity such as thermoregulation, spontaneous muscle contractions and posture maintenance. The remaining part of TEE $(10 \%)$ is spent in digestion, absorption, and sympathetic nervous system activation after the ingestion of a meal, in other words, it is the energy required to access the energy of the nutrients [46]. The peripheral tissues and organs, including the liver, the pancreas, the adipose tissues and the gastrointestinal tract, all build a highly complex system that contributes to the control of the energy balance in response to changes in the feeding state and the size of energy storage. The signals are integrated by neurons in the hypothalamus, resulting in an anorexigenic or orexigenic effect.

In the following paragraphs, we discuss the function of BDNF in both volitional and non-volitional physical activities.

\subsection{BDNF in Thermoregulation}

Thermogenesis is considered a non-volitional physical activity relevant to keeping body temperature within certain boundaries, even when the surrounding temperature is very different. Defined as the dissipation of energy to produce heat, thermogenesis occurs in BAT and skeletal muscle. BAT thermogenesis is controlled by the sympathetic drive, which is connected polysynaptically with neurons in the hypothalamus.

Several studies have reported the thermogenic effects of BDNF that can act both on hypothalamic neurons or on BAT. In mice, the ablation of BDNF results in deficits of BATmediated thermogenesis, impairments of the body temperature in response to cold, and finally, in obesity. At the molecular level, this is associated with the reduced expression of $\mathrm{UCP} 1$ and of the peroxisome proliferator-activated receptor-gamma coactivator (PGC1 $\alpha$ ), both involved in thermogenesis. UCP1 is a mitochondrial proton carrier that uncouples the respiratory chain from adenosine triphosphate (ATP) synthesis, allowing heat generation. PGC1 $\alpha$ is a transcription factor involved in energy metabolism (both carbohydrate and lipid metabolism) by regulating mitochondrial biogenesis [47].

Long-term peripherally administered BDNF increased body temperature and oxygen consumption [16] while hypothalamic injection of BDNF increased UCP1 mRNA and protein in BAT [48]. Furthermore, BDNF overexpression is suggested to induce the switching of white adipose tissue (WAT) to the BAT phenotype through sympathetic neuron activation in response to environmental stimuli [49]. The exogenous administration of BDNF regulates BAT thermogenesis through the brain control of sympathetic neurons. While BDNF infusion into the PVH increases energy expenditure coupled with an elevation of UCP1mediated thermogenesis [41], energy expenditure only, and not UCP1 levels, are increased when BDNF is injected into the VMH [50]. In the murine $\mathrm{DMH}$, neurons expressing BDNF are quickly activated by cold temperatures, and their activation is sufficient to increase body temperature, energy expenditure and physical activity [51]. Considering that BAT thermogenesis is the main component of energy expenditure in these animals, rodents use $\beta$-oxidation of fatty acids in BAT to maintain body temperature. Interestingly, although BAT was believed to be absent in adult humans, recent research reported a significant amount of metabolically active BAT involved in the regulation of thermogenesis in humans [52].

Overall, the findings discussed above provide evidence that BDNF has a role in the regulation of thermogenesis, and that this function is evolutionarily conserved.

\subsection{BDNF in Volitional Physical Activity}

Volitional physical activity consists of bodily movement produced by skeletal muscles both in daily life and in planned activities such as exercise or training. Both require energy expenditure and induce expression of BDNF in the skeletal muscle and in the brain, which performs its function in local and peripheral tissues. Many years of research have demonstrated the benefits of exercise for the brain. These benefits depend on BDNF release and result in the improvement of cognitive function in both animals and humans [53-55]. 
RNA expression data have demonstrated that the muscle is second to the brain for the BDNF expression level (Figure 1). BDNF mRNA expression is indeed increased upon contraction of muscular fibers, and the muscle can secrete BDNF into circulation [56,57]. Additionally, the BDNF receptor, TrkB, is upregulated in animals put under rigorous physical training $[58,59]$ or after the BDNF overexpression [60].

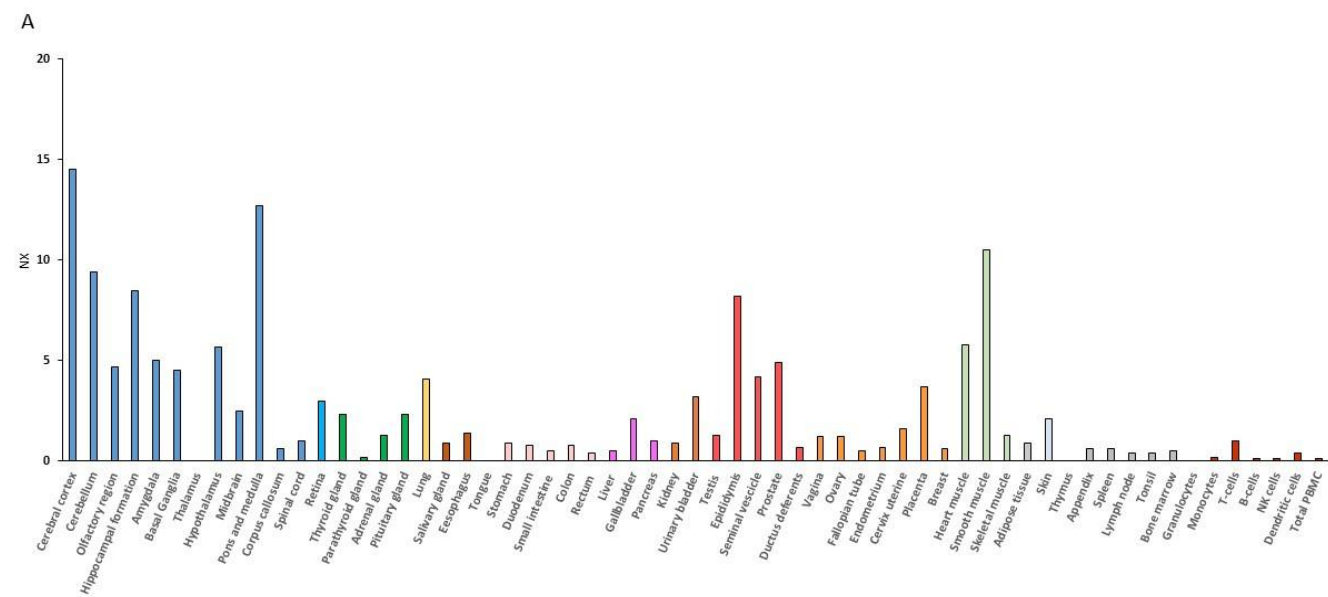

B

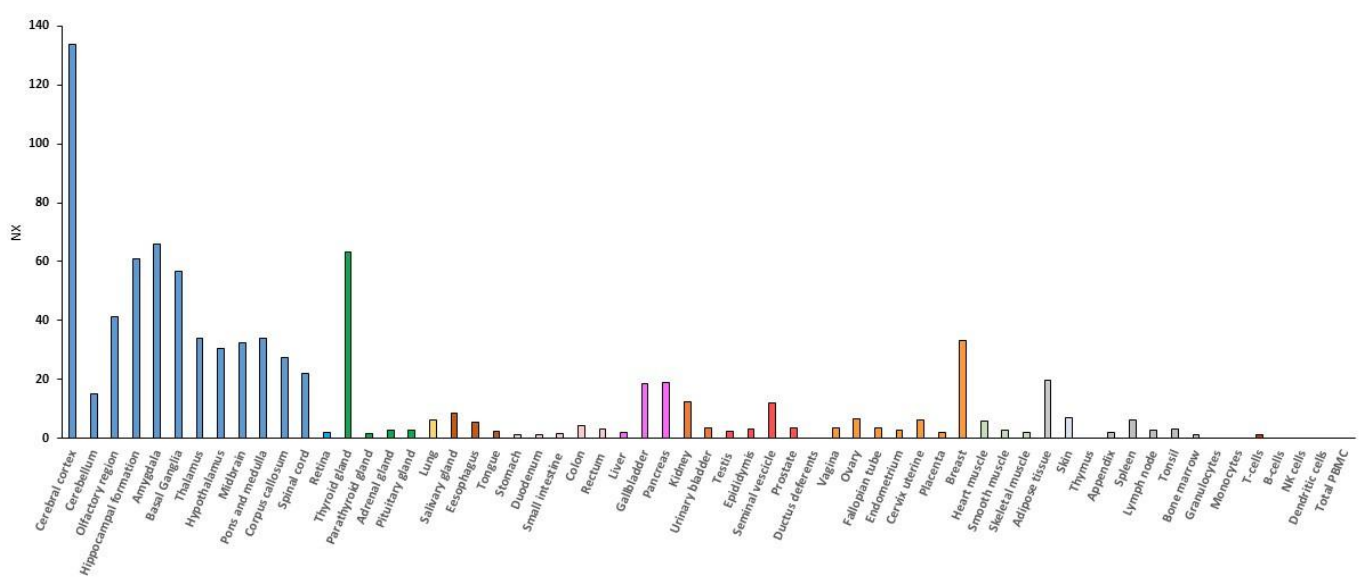

Figure 1. BDNF (A) and NTRK2 (B) RNA expression overview. NX indicates consensus normalized expression levels for 55 tissue types and 6 blood cell types, obtained by combining the RNA-data from three transcriptomics datasets (HPA, GTEx and FANTOM5) using the internal normalization pipeline. Each color indicates different groups consisting of tissues with common functional characteristics (source: Tissue expression of BDNF-Summary-The Human Protein Atlas; Tissue expression of NTRK2-Summary—The Human Protein Atlas).

Accordingly, in mice, Johnson et al. found that physical training leads to an increase in specific hippocampal BDNF expression, [61], resulting in stimulation of cognition and memory improvement [62].

However, evidence from human studies is much less direct. Several data indicate that physical activity stimulates the brain to produce and release more BDNF in order to improve muscle repair [63]. For instance, Rasmussen et al. by measuring the plasma BDNF levels during physical activity in humans, observed that BDNF increases two-to-three-fold during the exercise phase and begins to lower at rest $1 \mathrm{~h}$ later when the exercise has stopped. They calculated that the brain contributed to $70-80 \%$ of the circulating BDNF, either at rest or during the physical exercise, which suggest that through BDNF the brain participates to the tissue regeneration after muscle injury [63].

In a similar manner, Erickson and collaborators show that higher serum BDNF levels due to physical activity associates with increased hippocampal volume in the elderly. Based on a randomized controlled trial of 120 older adults, they found that aerobic exercise 
training increased hippocampal volume by $2 \%$, reversing age-related volume shrinkage. This correlates with higher serum levels of BDNF, suggesting again that physical exercise, through BDNF, stimulates cell repair and regeneration in several tissues [64].

Interestingly, another study highlighted the finely tuned regulation of BDNF release. It was reported that during physical training the amount of serum BDNF plateaued at longer running distances [65] revealing a physiological saturation mechanism that protects against potential excitotoxicity due to an excess of BDNF [66].

In the skeletal muscle, BDNF induced by exercise affects the physiology and morphology of fibers and is involved in the recovery of damaged muscles. These properties lead to consider BDNF as a myokine, although its role in neuromuscular physiology regulation in vivo remains unclear $[67,68]$.

In adult skeletal muscle, BDNF expression is found in myogenic progenitors known as satellite cells [69]; in healthy muscle, satellite cells are mitotically quiescent while they become activated in response to injury, triggering proliferation and differentiation to repair damaged fibers. In order to study the involvement of BDNF in muscle damage repair, Clow and Jasmin generated a mouse model in which BDNF is specifically depleted from skeletal muscle cells [70]. Moreover, after muscle injury BDNF expression is up-regulated when activation and proliferation of satellite cells occur [71]. Another study reports the up-regulation of BDNF in the extensor digitorum longus and tibialis anterior muscles of mice during the development period [72]. In this work, the authors demonstrated that the administration of BDNF prevented the loss of motor units (or the disappearance of muscle fibers) after neonatal nerve injury and contributed to the maintenance of muscle mass [72] The differential expression of BDNF in skeletal muscles, according to diverse physiological or pathological conditions, strengthens the notion that BDNF actively contribute to tissue recovery [73].

The influence of BDNF on skeletal muscle goes beyond regeneration and differentiation. Some evidence has demonstrated a role for BDNF in the energy metabolism and specification of skeletal muscular fibers. Delezie et al. have observed that muscles depleted of BDNF show higher succinate dehydrogenase activity, a mitochondrial enzyme involved in oxidative phosphorylation. Moreover, they demonstrated that the lack of BDNF contributes to the transformation from type IIB fibers, which have a low oxidative metabolism and are less efficient to fatigue, to type IIX fibers with a high oxidative capacity and are relatively efficient to fatigue. Conversely, BDNF overexpression increases the fast-type muscle gene expression, typical of type IIB fibers, such as Baf60c and Tbx15, and glycolytic markers, such as Serca1 and its coregulator Mlrn [74]. The involvement of BDNF in the glycolytic fiber-type specification was confirmed by Yamanaka et al. [75]. In this way, the BDNF-induced glucose uptake contributes to whole-body metabolism linked to the glycemic control since skeletal muscle is considered the most important storage of glucose upon insulin stimulation. The involvement of BDNF in thermoregulation and volitional physical activity is summarized in Table 3.

Table 3. Representative animal studies considering the role of BDNF in thermoregulation and volitional physical activity.

\begin{tabular}{|c|c|c|c|}
\hline Animal Model & Intervention/Stimuli & Effects & Reference \\
\hline Bdnf-e1 $1^{-/-}$mice & $\begin{array}{l}\text { Selective disruption } \\
\text { of Bdnf expression } \\
\text { from promoter } 1\end{array}$ & $\begin{array}{c}\text { Severe obesity, } \\
\text { deficits of } \\
\text { BAT-mediated } \\
\text { thermogenesis, } \\
\text { impairment of body } \\
\text { temperature response } \\
\text { to cold, } \\
\text { down-expression of } \\
\text { UCP1 and PCG1 } \alpha \\
\text { in BAT }\end{array}$ & $\begin{array}{c}\text { [47] You, H. et al., } \\
2020\end{array}$ \\
\hline
\end{tabular}


Table 3. Cont.

\begin{tabular}{|c|c|c|c|}
\hline Animal Model & Intervention/Stimuli & Effects & Reference \\
\hline $\begin{array}{l}\mathrm{C} 57 \mathrm{BL} / \mathrm{KsJ}-\mathrm{db} / \mathrm{db} \\
\text { mice (obese } \\
\text { diabetic mice) }\end{array}$ & $\begin{array}{c}\text { BDNF } \\
\text { subcutaneous } \\
\text { administration }\end{array}$ & $\begin{array}{l}\text { Increase in body } \\
\text { temperature and } \\
\text { oxygen consumption }\end{array}$ & $\begin{array}{l}\text { [16] Nakagawa, } \\
\text { T. et al., } 2000\end{array}$ \\
\hline $\begin{array}{l}\mathrm{C} 57 \mathrm{BL} / \mathrm{KsJ}-\mathrm{db} / \mathrm{db} \\
\text { mice (obese } \\
\text { diabetic mice) }\end{array}$ & $\begin{array}{l}\text { BDNF central } \\
\text { (ICV injection) and } \\
\text { subcutaneous } \\
\text { administration }\end{array}$ & $\begin{array}{l}\text { Increase in UCP1 } \\
\text { mRNA and protein in } \\
\text { BAT, modulation of } \\
\text { energy expenditure }\end{array}$ & $\begin{array}{l}\text { [48] Tsuchida, } \\
\text { A. et al., } 2001\end{array}$ \\
\hline $\begin{array}{l}\text { Diet-induced obese } \\
\text { (DIO) C57BL/6 mice }\end{array}$ & $\begin{array}{l}\text { Injection of a rAAV } \\
\text { vector expressing the } \\
\text { human BDNF gene in } \\
\text { the hypothalamus }\end{array}$ & $\begin{array}{l}\text { Reproduction of the } \\
\text { effects induced by } \\
\text { enriched } \\
\text { environment: } \\
\text { activation of the } \\
\text { brown fat gene } \\
\text { program ("browning" } \\
\text { of WAT) and } \\
\text { lean phenotype }\end{array}$ & $\begin{array}{l}\text { [49] Cao, L. et al., } \\
2011\end{array}$ \\
\hline Sprague-Dawley rats & $\begin{array}{l}\text { BDNF injection into } \\
\text { the VMH }\end{array}$ & $\begin{array}{l}\text { Body weight } \\
\text { reduction by } \\
\text { decreasing food } \\
\text { intake and increasing } \\
\text { energy expenditure }\end{array}$ & $\begin{array}{l}\text { [50] Wang, C. et al., } \\
2010\end{array}$ \\
\hline Wistar rats & $\begin{array}{l}\text { One week of forced } \\
\text { moderate exercise }\end{array}$ & $\begin{array}{l}\text { Improvement in } \\
\text { spatial memory, } \\
\text { increase in BDNF } \\
\text { mRNA expression in } \\
\text { the dentate gyrus }\end{array}$ & $\begin{array}{l}\text { [53] Bechara, } \\
\text { R.G. et al., } 2014\end{array}$ \\
\hline C57BL/6 mice & $\begin{array}{l}\text { Long-term physical } \\
\text { exercise ( } 4 \text { weeks of } \\
\text { treadmill and running } \\
\text { wheel exercise) }\end{array}$ & $\begin{array}{c}\text { Hippocampal } \\
\text { increase in: (i) BDNF } \\
\text { mRNA and protein } \\
\text { (ii) synaptic load (iii) } \\
\text { TrkB receptor levels } \\
\text { in astrocytes }\end{array}$ & $\begin{array}{l}\text { [58] Fahimi, A. et al., } \\
2017\end{array}$ \\
\hline \multirow{2}{*}{ Sprague-Dawley rats } & $\begin{array}{c}\text { Short exercise period } \\
\text { (voluntary } \\
\text { exercise paradigm) }\end{array}$ & $\begin{array}{l}\text { Enhancement in } \\
\text { spatial learning and } \\
\text { memory; increase in } \\
\text { the mRNA levels of } \\
\text { BDNF, TrkB receptor, } \\
\text { synapsin I and CREB }\end{array}$ & \multirow{2}{*}{$\begin{array}{l}\text { [62] Vaynman, } \\
\text { S. et al., } 2004\end{array}$} \\
\hline & $\begin{array}{l}\text { Injection of a BDNF } \\
\text { blocker into the } \\
\text { hippocampus before } \\
\text { the start of } \\
\text { wheel running }\end{array}$ & $\begin{array}{l}\text { Block of exercise } \\
\text { benefits (reduction in: } \\
\text { mRNA levels of } \\
\text { BDNF, TrkB receptor, } \\
\text { synapsin I and CREB) }\end{array}$ & \\
\hline $\begin{array}{c}\text { Muscle-specific } \\
\text { BDNF Knockout Mice } \\
\left(\text { BDNF }^{\mathrm{MKO}}\right)\end{array}$ & Muscle injury & $\begin{array}{c}\text { Abnormal myogenic } \\
\text { differentiation } \\
\text { and regeneration }\end{array}$ & $\begin{array}{c}\text { [70] Clow, C.; Jasmin, } \\
\text { B.J., } 2010\end{array}$ \\
\hline $\begin{array}{l}\mathrm{C} 57 \mathrm{BL} / \mathrm{KsJ}-\mathrm{db} / \mathrm{db} \\
\text { mice (obese } \\
\text { diabetic mice) }\end{array}$ & $\begin{array}{c}\text { Chronic } \\
\text { subcutaneous } \\
\text { administration } \\
\text { of BDNF }\end{array}$ & $\begin{array}{l}\text { Improvement of } \\
\text { glucose metabolism: } \\
\text { enhancement of } \\
\text { glucose utilization in } \\
\text { peripheral tissues } \\
\text { (skeletal muscle, } \\
\text { heart, BAT and liver) }\end{array}$ & $\begin{array}{l}\text { [75] Yamanaka, } \\
\text { M. et al., } 2007\end{array}$ \\
\hline
\end{tabular}




\subsection{BDNF, Mitochondria and the Regulation of Cellular Bioenergetics}

While it is well recognized that the exercise-induced BDNF has implications on neuronal metabolism, [76] how BDNF modulation during exercise can influence specific aspects of cognitive function is poorly understood.

Research on the topic pointed out that, when upregulated due to physical exercise, BDNF can affect mitochondrial metabolism in the CNS [2]. In the hippocampus, in the cortex and in the cerebellum, the upregulation of BDNF stimulates PGC-1 $\alpha$ expression which is involved in mitochondrial biogenesis and modulates autophagy with many beneficial effects [77-80]. Similar to many other genes involved in vital processes for the cell and the organism, PGC1 $\alpha$ expression is controlled by the transcription factor CREB (cyclic AMP response element-binding protein) via phosphorylation. In particular, $\mathrm{BDNF}$ induces $\mathrm{Ca}^{2+}$ influx through the TRPC (transient receptor potential C) channels. The consequent intracellular $\mathrm{Ca}^{2+}$ rise, activates the $\mathrm{Ca}^{2+} /$ calmodulin-dependent protein kinase (CaMK), resulting in CREB phosphorylation/activation. Phospho-CREB, in turn, stimulates PGC- $1 \alpha$ expression, which increases the mitochondria content. Thus, BDNF indirectly ensures more energy substrates (ATP and NAD+) to support the adaptive plasticity and the formation of synapses [81]. Interestingly, NAD+ induces sirtuin-1 (Sirt1) expression, a deacetylase that can activate the transcription factor FOXO3a, resulting in the production of the mitochondrial antioxidant enzyme MnSOD (manganese superoxide dismutase) [80]. This evidence suggests that BDNF is also involved in antioxidant defense. Moreover, the exercise-dependent PGC- $1 \alpha$-activation in the brain stimulates the expression of FNDC5 [82]. FNDC5 is a myokine, cleaved and secreted as irisin during exercise, which mediates the metabolic benefits of exercise [83]. Notably, FNDC5 was shown to regulate BDNF release in the hippocampus and secreted irisin induces the "browning" of adipose tissues. This reinforces the idea of the wide beneficial effects of exercise on the entire organism.

Exercise can differently influence young and old organisms. Gusdon et al. analyzed the mitochondrial functionality and the pathways regulating mitochondrial biogenesis both in young and old mice. After three weeks of physical training, the functionality of the mitochondrial electron transport chain complex I, but not complex II, is improved in old mice. The improvement in mitochondrial functionality is limited to old mice since young mice did not show differences following the training. This was associated with increased BDNF levels. Furthermore, in old mice, cortical neurons do not exhibit increased brain mitochondrial protein expression or mitochondrial biogenesis following exercise, but rather elevated DRP1 levels (dynamin related protein-1), suggesting an enhanced mitochondrial transport or turnover by fission. Mitochondrial fission is indeed needed for the effective autophagic clearance of damaged mitochondria [84]. The direct impact of BDNF on complex I functionality is described by Markham et al. They found BDNF action to be specific for brain mitochondria, with no effect in liver mitochondrial preparations [85]. Moreover, the authors confirmed that the improvement of mitochondrial respiration is reached through the MEK-MAPK pathway [86]. Thus, the specific effect of BDNF on complex I activity, may have marked implications for neurodegenerative and psychiatric diseases associated with impaired mitochondrial metabolism.

In the hippocampus, the inhibition of BDNF activity during exercise training decreases the mRNA levels for AMPK (AMP-activated protein kinase), uMtCK (ubiquitous mitochondrial creatine kinase), UCP2 (uncoupling protein 2), ghrelin, and IGF-I (insulin-like growth factor-I) [87]. These proteins normally increase after exercise and are relevant in the regulation of bioenergetics. AMPK increases the cellular energy supply by switching on catabolic pathways to generate ATP and shutting off processes that dissipate it, through the phosphorylation of metabolic enzymes. The mitochondrial phosphocreatine uMtCK, can buffer the elevated ATP consumption by donating its phosphate group to ADP, providing a mechanism to protect neurons during periods of increased energy demand. $\mathrm{UCP} 2$ is an isoform of the mitochondrial uncoupling protein, expressed in many different tissues, including the kidney, liver, gastrointestinal tract, brain, and skeletal muscle. UCP2 enhances energy expenditure and protects neonatal neurons from excitotoxic cell death, 
inhibiting reactive oxygen species production and preventing mitochondrial dysfunction. IGF1 is shown to protect cultured hippocampal neurons from serum deprivation-induced cell death using similar downstream pathways [76,87]. Although the IGF-I receptor is abundantly expressed in the hippocampus, IGF-I can also be produced in peripheral tissue, such as in skeletal muscle and liver in response to exercise. Finally, ghrelin is generally secreted from the oxyntic glands of the stomach [88] in response to energy restriction and/or depletion.

\section{The Role of BDNF in the Peripheral Control of Energy Balance}

In the previous paragraphs, we have discussed the BDNF involvement in the regulation of energetic metabolism and the way it is achieved through the modulation of the mitochondrial function, related to physical exercise. Alongside these concepts, BDNF seems to actively participate in nutrient uptake control in different types of cells, thus defining the differentiation of the given cell type toward a distinct physiological function.

Energy requests, both in the basal state and during exercise, are covered by two major substrates: glucose and free fatty acids (FFA). Conversely, protein oxidation occurs for the protein taken with the diet and contributes $10 \%$ to $15 \%$ of TEE. Glucose and FFA can be considered interchangeable as intermediate metabolites in most tissues, but the brain relies almost exclusively on glucose metabolism [46].

During postnatal brain development, BDNF signaling increases glucose and amino acid uptake, playing a determinant role in the response to the increased energy demand and protein synthesis associated with neuronal differentiation. In fact, in the brain, 50\% of the total energy consumption is used to restore ion gradients and resting membrane potentials by $\mathrm{Na}+/ \mathrm{K}+-$ ATPase [89] useful to synaptic plasticity and electrical stimulation. Notably, in cortical neurons, 20 min BDNF exposure increases GLUT3 (neuronal glucose transporter) mRNA and protein levels, thus enhancing glucose utilization by increasing its uptake. This effect requires TrkB receptor activation and the PLC signaling pathway and is specific for cortical neurons since it is not described in cortical astrocytes [90].

BDNF participates in the regulation of peripheral energy metabolism by directly acting on those cells which are strictly involved in the glucose homeostasis such as pancreatic $\beta$ cells and hepatocytes [91].

In peripheral tissues, glucose homeostasis is under the regulation of insulin signaling. In fact, in the liver of diabetic mice, BDNF treatment enhances the tyrosine phosphorylation of the insulin receptor which in turn trigger PI3-K signaling [92,93]. The reduction in blood glucose levels is associated with an increase in the number and total area of pancreatic islets and with an increase in secretory granules in $\beta$-cells [94]. It has been demonstrated that the synergistic effect of BDNF and glucose levels induces insulin release from pancreatic $\beta$-cells. In mice, the synergistic effect happens when blood glucose levels are high; in humans, insulin is released from islets, even in the presence of lower blood glucose levels. This is likely due to the intrinsic differences between mouse and human $\beta$-cells. Notably, their sensitivity to glucose as well as the expression of different ion channels, might influence $\beta$-cell sensitivity to intracellular $\mathrm{Ca}^{2+}$ levels induced by BDNF/TrkB signaling [57].

Furthermore, glucagon levels seem to be influenced by BDNF. Infusion of BDNF into the rat brains results in decreased glucagon levels in the portal vein. This effect is abrogated by the denervation of pancreatic efferent nerves [95]. Moreover, it is observed that the intraportal administration of GLP-1 (glucagon-like peptide 1) increases BDNF levels in the pancreas and reduces glucagon secretion. GLP-1 receptors are expressed in the pancreas, muscle, liver and also in neurons throughout the brain. The activation of GLP-1 receptors results in cyclic AMP production and in the activation of CREB which is known to induce BDNF expression. Similar to GLP-1, BDNF signaling increases glucose uptake by liver, skeletal and cardiac muscle cells [75].

BDNF might also be considered as anadipokine since it is expressed in both BAT and WAT $[96,97]$. In particular, significant changes in BDNF and NTRK2 expression are observed in the adipose tissue of obese mice (NTRK2 is downregulated by adipocytes, in 
contrast, BDNF is upregulated by other cells) implying that BDNF may have a role in the regulation of systemic metabolism [98] Other studies, performed in rats, demonstrated the activation of BDNF and TrkB-expressing neurons located in sympathetic outflow circuitry that ultimately innervate WAT, the tissue where lipolysis is stimulated. This sympathetic activation is responsible for the increase in circulating FFA and glycerol concentrations and for the decrease in body fat mass [99].

All these literature data allow the consideration of BDNF as a metabolic modulator that coordinates the adaptive response of the brain and the body to fluctuations in energy intake and expenditure; for this reason, it was defined as "metabokine", meaning a pleiotropic signaling molecule [100].

In hypothalamic neurons, BDNF influences food intake through the activation of mTORC1 (mTOR complex 1). Similar to insulin, BDNF binds tyrosine kinase receptor, thus activating the PI3-K/Akt pathway $[28,101,102]$. The activation of mTORC1 stimulates protein synthesis and lipid biosynthesis resulting in cellular mass gain and reduced food intake needs. Notably, it is demonstrated that BDNF can act through different signal transduction pathways, mTOR and AMPK, although they work oppositely (i.e., when intracellular energy is abundant, mTOR activity is increased and AMPK activity is decreased, and vice versa) $[103,104]$. The types of signaling pathway activated depend on the tissue where BDNF acts. In myotubes and in contracting muscle BDNF promotes catabolic pathways, increasing $\beta$-oxidation through AMPK signaling that activates acetyl coenzyme A carboxylase $(\mathrm{ACC} \beta)$ and consequently enhances fat oxidation and inhibits fat synthesis $[56,67,105]$. Similarly, in hepatocytes, BDNF activates the same molecular mechanism but this results in increased fatty acid oxidation, glycogen storage and inhibition of gluconeogenesis [106].

\section{BNDF Involvement in Neurodegenerative Disorders}

It is known that the pathos-physiological modifications associated with several neurodegenerative diseases begins decades before the emergence of clinical symptoms. One of these changes is the impairment in the brain energy metabolism. The brain, indeed, has high energy requirements, as it employs most of the glucose for the maintenance of synaptic functions and of neuronal resting potentials. As broadly discussed throughout this manuscript, among other functions, BDNF is closely involved in the regulation of energy balance, and BDNF levels are influenced by physical activities. Alongside being essential for the survival and phenotypic maintenance of mature, fully developed neurons, BDNF is recognized to modulate several neuronal functions, such as axonal growth, long-term potentiation, which is pivotal for the development of learning and memory. Therefore, it is not surprising that BDNF is implicated in several neurodegenerative diseases, including Alzheimer's (AD), Parkinson's (PD), Huntington's (HD) diseases and other neuropsychiatric disorders [107,108].

The first evidence implicating BDNF in AD and PD dates back to the 1990's, and for both pathologies, reduced levels of mRNA or proteins were described either in postmortem brains of humans or mice models [109-112]. Lower BDNF mRNA expression was reported in the hippocampus, neocortex, in the Meynert nucleus basalis, all of which are regions selectively vulnerable to the degeneration in AD [110]. Reduced BDNF levels were also associated to the presence of neurofibrillary tangles, a hallmark of AD [113]. Accordingly, the withdrawal of BDNF in cultured hippocampal neurons or BDNF depletion in mice also resulted in differential expression of genes implicated in AD. More importantly, genetic delivery of BDNF in primate and rodent models of ADreduce synaptic loss and improve learning and memory formation [114].

As in AD, reduced expression of BDNF mRNA and protein are found in dopaminergic neurons of the substantia nigra, a region of the brain where PD-affected neurons are localized [110,115,116]. This notion was confirmed when many classical features of animal PD models were reproduced by blocking the BDNF expression in the substantia nigra of rats [117]. Accordingly, Wnt-BDNFKO mice, completely lacking BDNF in the midbrain and hindbrain, show a persistent reduction of dopaminergic neurons in the substantia 
nigra [118]. In addition, reduced BDNF production is closely associated with pathogenic mutations in $\alpha$-synuclein in familial PD [119,120].

The assessment of BDNF levels in human postmortem cerebral cortex samples indicated that BDNF production was also impaired in the brains of HD patients [121,122]. Several works confirmed the reduction of BDNF levels in a large panel of huntingtin (Htt) knock-out mice, indicating that a decrease in cortical BDNF levels occur early in the disease and that it is partly due to the lower stimulatory activity of wild type Htt. Indeed, the increase or decrease in wild-type Htt levels in mouse models augments or reduces, respectively, the transcription from the BDNF promoter [123,124]. Accordingly, Htt is thought to play a role in the transport and activity-dependent release of BDNF $[123,125]$. Thus, mutations in the Htt protein result in "loss of function", greatly affecting BDNF levels in striatal neurons.

BDNF is reported to slow the progression of motor neuron atrophy in an animal model of amyotrophic lateral sclerosis (ALS) [126], and the TrkB agonist 7,8-dihydroxyflavone (7,8-DHF) improved motor neuron deficits in the superoxide dismutase 1 (SOD1G93A) ALS mouse models [127].

Recent clinical studies have also demonstrated an association between low levels of BDNF and depressive disorders. Accordingly, BDNF infusion produces anti-depressive-like effects in the mouse midbrain of depression mice models [128]. Finally, in the hippocampus, prefrontal cortex, anterior cingulate cortex and superior temporal gyrus of schizophrenia patients, BDNF mRNA and protein levels have been found to be lower than in the controls [129-131].

The above-mentioned findings, which demonstrated that levels of neurotrophins influence the progression of neurodegenerative disorders, are the rationale for developing therapeutic approaches based on the modulation of BDNF levels.

The first clinical trial considering the application of BDNF infusions in neurodegenerative diseases was performed in ALS patients but failed to demonstrate a statistically significant effect of BDNF on patients survival $[132,133]$. It is possible that the poor pharmacokinetics associated with the intact protein, the BDNF short in vivo half-life, the limited diffusion and low penetrability of the blood-brain barrier has hindered progress towards a therapeutic strategy. Consequently, since pharmacological treatments are not available, other remedies are found to delay the course of the disease: physical exercise, enriched environment, hormonal balance (i.e., steroid hormones such a cortisol and testosterone) and nutritional intervention (i.e., fasting, low-calorie intake, low-carb diet, selective nutrient intakes). Among them, epidemiological studies have found that physical activity reduces the risk of $\mathrm{AD}$ and dementia by $45 \%$ and $28 \%$, respectively [134] and are capable to rescue BDNF levels [135]. In agreement with these results, preliminary findings indicate that in healthy individuals the deposition of plaque/tangle in the brain inversely correlate with an healthy life style (normal body weight, regular physical activity, and healthy diet) [136].

The research on neurodegenerative diseases discussed above, strengthens the concept that BDNF levels are influenced by physical activities. However, the underlying molecular mechanisms explaining these findings are unknown. Based on findings from animal models, Mattson proposed that physical activity and intermittent energy restriction can together hinder neurodegenerative processes and improve brain function supporting the neuronal adaptive stress response including DNA repair, neurotrophic signaling, mitochondrial biogenesis [137]. Physical exercise downregulates Bax and neuro-inflammatory cytokines in the hippocampus [138,139], reduces chronic oxidative stress and promotes mitochondrial biogenesis. Porrit and collaborators [117] reported that BDNF overexpression decreases the expression of PINK1, an integral protein which governs mitochondrial quality control [140], and restores the activity of key enzymes (complex I, complex II+III) in the mitochondrial respiratory chain. Others have shown that the pathways by which exercise-induced neuronal BDNF might involve the co-activation of PGC- $1 \alpha$, leading to the activation of fibronectin type III domain-containing protein 5 (Fndc5) gene expression [82]. Accordingly, exercise is known to enhance the activities of BDNF regulating transcription 
factors CREB and NF- $\mathrm{kB}$ [141] which can act in cooperation with FNDC5. On the other hand, several reports indicate that factors enhancing glucose uptake and glycolytic flux (e.g., Wnt3a) or regulating mitochondrial functions could be beneficial in AD, PD, ALS and in other neuropathological conditions [142].

From a unitary perspective, brain metabolism is intended to equate oxygen consumption to glucose utilization. However, the concept of increased non-oxidative glucose consumption during physiologic neural activity has recently gained a lot of consideration. Enhanced aerobic glycolysis and increased lactate production are recognized as common properties of invasive cancers and its up regulation in cancer results in the suppression of apoptosis. This phenomenon, termed the Warburg effect, is progressively being recognized as well in the CNS as an adaptive response which would provide selective advantages for neuronal survival. Our group previously reported on a neuro-protective effect of monomeric $A \beta$ in vitro which is directly connected to the regulation of glucose utilization in neurons [143]. This effect mediated by the IGF-IR and the ensuing PI3K pathway, results from the stimulation of the CREB target genes including BDNF [144]. Most recently, we have demonstrated that in response to the inhibition of oxidative phosphorylation, cultured cortical neurons increased aerobic glycolysis. This increase depends on the stimulation of the PI3K pathway and involves the activation of AKT, a master regulator of survival/apoptosis which targets various proteins including hexokinase (HK). $\mathrm{HK}$ is mainly associated with the outer mitochondrial membrane [145]. Mitochondrialbound HKI supports neurons and the HK-released from mitochondria decreases in enzyme activity and triggers apoptosis in cells.

On these premises, we speculate that, by stimulating specific pathways, BDNF prompts neurons to exploit either oxidative phosphorylation or aerobic glycolysis in order to quickly fuel neurons with the necessary energy to properly absolve their functions. This would represent a physiological homeostatic mechanism to ensure synaptic plasticity. Consequently, a reduction in BDNF and other neurotrophins, as occurring in aging and in diverse neuropathological conditions, might impair the neuronal ability to cope with transient needs in energy provision.

\section{Conclusions}

The incidence of obesity and metabolic diseases among children, adolescents and adults is progressively increasing across the globe. Derived from an imbalance between food intake and energy expenditure, metabolic disorders augment the risk of cardiovascular and neurodegenerative diseases, negatively affecting people's lifestyles.

Strong evidence from genetic and pharmacological studies highlights the crucial role of BDNF in controlling energy homeostasis. As a metabolic modulator, BDNF coordinates the adaptive response to fluctuations in energy intake and expenditure mediating signal transfer through a complex network between the CNS and peripheral tissues (Figure 2).

The energy balance can be maintained through a healthy lifestyle including diet and volitional physical activity. Interestingly, a large amount of data supports the involvement of BDNF in the realization of beneficial effects induced by physical exercise. The identification of circuitry which integrates signals from food intake and energy expenditure and the elucidation of the mechanisms by which BDNF acts on them will lay the groundwork in building a healthy and balanced life and deepening the comprehension of human metabolic diseases. The resulting knowledge could have important implications for human health, leading people to maintain healthy bodies and minds, and encouraging the identification of novel strategies for treating metabolic disorders. 

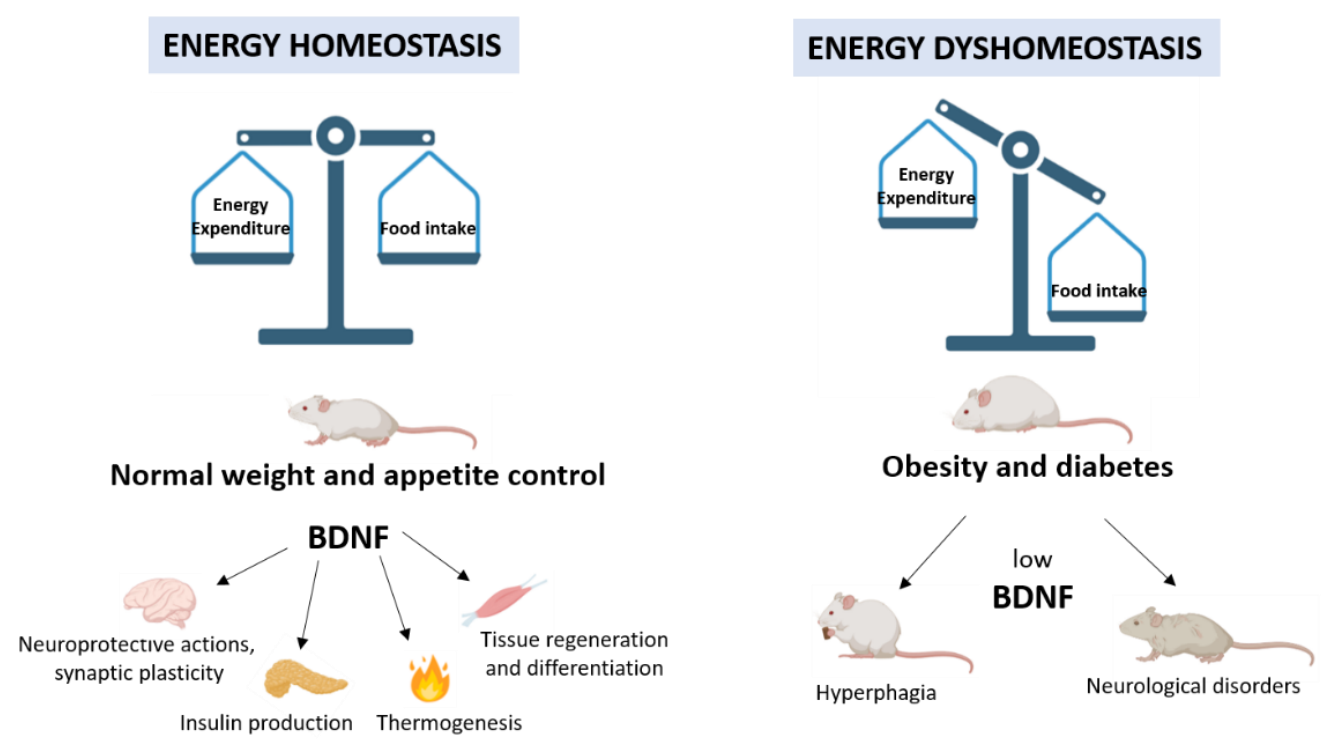

Figure 2. Schematic drawing of BDNF involvement in energy homeostasis. BDNF modulates numerous pathways related to food intake and weight control not only via the brain but also via peripheral neurons and tissues involved in preserving energy balance. When food intake exceeds energy expenditure, pathological conditions (obesity and diabetes) may occur.

Author Contributions: Writing-review and editing, M.C.D.R., S.Z. and M.W.S.; Supervision, reviewing and editing, M.F.T. All authors have read and agreed to the published version of the manuscript.

Funding: This research received no external funding. M.C.D. was supported by PRIN post-doctoral fellow by MIUR (PRIN 2015 prot. 2015795S5W_005).

Institutional Review Board Statement: Not applicable.

Informed Consent Statement: Not applicable.

Data Availability Statement: Not applicable.

Acknowledgments: The authors are grateful to Vito De Pinto (the University of Catania) and Francesco Attanasio (Institute of Crystallography, CNR, Catania) for the support, and to Rigel Villagonzalo Rountree for his assistance with English editing. Authors also acknowledge Biotechnology PhD courses.

Conflicts of Interest: The authors declare no conflict of interest.

\section{References}

1. Sasi, M.; Vignoli, B.; Canossa, M.; Blum, R. Neurobiology of Local and Intercellular BDNF Signaling. Pflugers Arch 2017, 469, 593-610. [CrossRef]

2. Marosi, K.; Mattson, M.P. BDNF Mediates Adaptive Brain and Body Responses to Energetic Challenges. Trends Endocrinol. Metab. 2014, 25, 89-98. [CrossRef]

3. Noble, E.E.; Billington, C.J.; Kotz, C.M.; Wang, C. The Lighter Side of BDNF. Am. J. Physiol. Regul Integr. Comp. Physiol. 2011, 300, R1053-R1069. [CrossRef]

4. Yang, J.; Siao, C.-J.; Nagappan, G.; Marinic, T.; Jing, D.; McGrath, K.; Chen, Z.-Y.; Mark, W.; Tessarollo, L.; Lee, F.S.; et al. Neuronal Release of ProBDNF. Nat. Neurosci. 2009, 12, 113-115. [CrossRef]

5. Kowiański, P.; Lietzau, G.; Czuba, E.; Waśkow, M.; Steliga, A.; Moryś, J. BDNF: A Key Factor with Multipotent Impact on Brain Signaling and Synaptic Plasticity. Cell. Mol. Neurobiol. 2018, 38, 579-593. [CrossRef] [PubMed]

6. Hempstead, B.L. Brain-Derived Neurotrophic Factor: Three Ligands, Many Actions. Trans. Am. Clin. Clim. Assoc. 2015, 126, 9-19.

7. Je, H.S.; Yang, F.; Ji, Y.; Nagappan, G.; Hempstead, B.L.; Lu, B. Role of Pro-Brain-Derived Neurotrophic Factor (ProBDNF) to Mature BDNF Conversion in Activity-Dependent Competition at Developing Neuromuscular Synapses. Proc. Natl. Acad. Sci. USA 2012, 109, 15924-15929. [CrossRef]

8. Blum, R.; Konnerth, A. Neurotrophin-Mediated Rapid Signaling in the Central Nervous System: Mechanisms and Functions. Physiology (Bethesda) 2005, 20, 70-78. [CrossRef] 
9. Xu, B.; Xie, X. Neurotrophic Factor Control of Satiety and Body Weight. Nat. Rev. Neurosci. 2016, 17, 282-292. [CrossRef]

10. Rios, M. Neurotrophins and the Regulation of Energy Balance and Body Weight. Handb. Exp. Pharmacol. 2014, $220,283-307$. [CrossRef] [PubMed]

11. Podyma, B.; Parekh, K.; Güler, A.D.; Deppmann, C.D. Metabolic Homeostasis via BDNF and Its Receptors. Trends Endocrinol. Metab. 2021, 32, 488-499. [CrossRef] [PubMed]

12. Rios, M. BDNF and the Central Control of Feeding: Accidental Bystander or Essential Player? Trends Neurosci. 2013, 36, 83-90. [CrossRef] [PubMed]

13. Lapchak, P.A.; Hefti, F. BDNF and NGF Treatment in Lesioned Rats: Effects on Cholinergic Function and Weight Gain. Neuroreport 1992, 3, 405-408. [CrossRef]

14. Pelleymounter, M.A.; Cullen, M.J.; Wellman, C.L. Characteristics of BDNF-Induced Weight Loss. Exp. Neurol. 1995, 131, 229-238. [CrossRef]

15. Nonomura, T.; Tsuchida, A.; Ono-Kishino, M.; Nakagawa, T.; Taiji, M.; Noguchi, H. Brain-Derived Neurotrophic Factor Regulates Energy Expenditure through the Central Nervous System in Obese Diabetic Mice. Int. J. Exp. Diabetes Res. 2001, 2, $201-209$. [CrossRef]

16. Nakagawa, T.; Tsuchida, A.; Itakura, Y.; Nonomura, T.; Ono, M.; Hirota, F.; Inoue, T.; Nakayama, C.; Taiji, M.; Noguchi, H. Brain-Derived Neurotrophic Factor Regulates Glucose Metabolism by Modulating Energy Balance in Diabetic Mice. Diabetes 2000, 49, 436-444. [CrossRef] [PubMed]

17. Kernie, S.G.; Liebl, D.J.; Parada, L.F. BDNF Regulates Eating Behavior and Locomotor Activity in Mice. EMBO J. 2000, 19, 1290-1300. [CrossRef]

18. Yeo, G.S.H.; Connie Hung, C.-C.; Rochford, J.; Keogh, J.; Gray, J.; Sivaramakrishnan, S.; O’Rahilly, S.; Farooqi, I.S. A de Novo Mutation Affecting Human TrkB Associated with Severe Obesity and Developmental Delay. Nat. Neurosci. 2004, 7, 1187-1189. [CrossRef]

19. Gray, J.; Yeo, G.S.H.; Cox, J.J.; Morton, J.; Adlam, A.-L.R.; Keogh, J.M.; Yanovski, J.A.; El Gharbawy, A.; Han, J.C.; Tung, Y.C.L.; et al. Hyperphagia, Severe Obesity, Impaired Cognitive Function, and Hyperactivity Associated with Functional Loss of One Copy of the Brain-Derived Neurotrophic Factor (BDNF) Gene. Diabetes 2006, 55, 3366-3371. [CrossRef]

20. Han, J.C.; Liu, Q.-R.; Jones, M.; Levinn, R.L.; Menzie, C.M.; Jefferson-George, K.S.; Adler-Wailes, D.C.; Sanford, E.L.; Lacbawan, F.L.; Uhl, G.R.; et al. Brain-Derived Neurotrophic Factor and Obesity in the WAGR Syndrome. N. Engl. J. Med. 2008, 359, 918-927. [CrossRef]

21. Mou, Z.; Hyde, T.M.; Lipska, B.K.; Martinowich, K.; Wei, P.; Ong, C.-J.; Hunter, L.A.; Palaguachi, G.I.; Morgun, E.; Teng, R.; et al. Human Obesity Associated with an Intronic SNP in the Brain-Derived Neurotrophic Factor Locus. Cell Rep. 2015, 13, $1073-1080$. [CrossRef] [PubMed]

22. Han, J.C. Rare Syndromes and Common Variants of the Brain-Derived Neurotrophic Factor Gene in Human Obesity. Prog. Mol. Biol. Transl. Sci. 2016, 140, 75-95. [CrossRef] [PubMed]

23. Gray, J.; Yeo, G.; Hung, C.; Keogh, J.; Clayton, P.; Banerjee, K.; McAulay, A.; O’Rahilly, S.; Farooqi, I.S. Functional Characterization of Human NTRK2 Mutations Identified in Patients with Severe Early-Onset Obesity. Int. J. Obes. (Lond) 2007, 31, 359-364. [CrossRef]

24. Krabbe, K.S.; Nielsen, A.R.; Krogh-Madsen, R.; Plomgaard, P.; Rasmussen, P.; Erikstrup, C.; Fischer, C.P.; Lindegaard, B.; Petersen, A.M.W.; Taudorf, S.; et al. Brain-Derived Neurotrophic Factor (BDNF) and Type 2 Diabetes. Diabetologia 2007, 50, 431-438. [CrossRef] [PubMed]

25. Rosas-Vargas, H.; Martínez-Ezquerro, J.D.; Bienvenu, T. Brain-Derived Neurotrophic Factor, Food Intake Regulation, and Obesity. Arch. Med. Res. 2011, 42, 482-494. [CrossRef]

26. Vidović, V.; Maksimović, N.; Novaković, I.; Damnjanović, T.; Jekić, B.; Vidović, S.; Majkić Singh, N.; Stamenković-Radak, M.; Nikolić, D.; Marisavljević, D. Association of the Brain-Derived Neurotrophic Factor Val66Met Polymorphism with Body Mass Index, Fasting Glucose Levels and Lipid Status in Adolescents. Balk. J. Med. Genet. 2020, 23, 77-82. [CrossRef]

27. Ieraci, A.; Barbieri, S.S.; Macchi, C.; Amadio, P.; Sandrini, L.; Magni, P.; Popoli, M.; Ruscica, M. BDNF Val66Met Polymorphism Alters Food Intake and Hypothalamic BDNF Expression in Mice. J. Cell. Physiol. 2020, 235, 9667-9675. [CrossRef]

28. Takei, N.; Furukawa, K.; Hanyu, O.; Sone, H.; Nawa, H. A Possible Link between BDNF and MTOR in Control of Food Intake. Front. Psychol. 2014, 5, 1093. [CrossRef]

29. Sonoyama, T.; Stadler, L.K.J.; Zhu, M.; Keogh, J.M.; Henning, E.; Hisama, F.; Kirwan, P.; Jura, M.; Blaszczyk, B.K.; DeWitt, D.C.; et al. Human BDNF/TrkB Variants Impair Hippocampal Synaptogenesis and Associate with Neurobehavioural Abnormalities. Sci. Rep. 2020, 10, 9028. [CrossRef]

30. Castro-Coyotl, D.M.; Crisanto-López, I.E.; Hernández-Camacho, R.M.; Saldaña-Guerrero, M.P. Atypical Presentation of CharcotMarie-Tooth Disease Type 2Q by Mutations on DHTKD1 and NTRK2 Genes. Bol. Med. Hosp. Infant. Mex. 2021, 78, 474-478. [CrossRef]

31. Liao, G.-Y.; Bouyer, K.; Kamitakahara, A.; Sahibzada, N.; Wang, C.-H.; Rutlin, M.; Simerly, R.B.; Xu, B. Brain-Derived Neurotrophic Factor Is Required for Axonal Growth of Selective Groups of Neurons in the Arcuate Nucleus. Mol. Metab. 2015, 4, 471-482. [CrossRef] [PubMed]

32. Liao, G.-Y.; An, J.J.; Gharami, K.; Waterhouse, E.G.; Vanevski, F.; Jones, K.R.; Xu, B. Dendritically Targeted Bdnf MRNA Is Essential for Energy Balance and Response to Leptin. Nat. Med. 2012, 18, 564-571. [CrossRef] 
33. Friedman, J.M.; Halaas, J.L. Leptin and the Regulation of Body Weight in Mammals. Nature 1998, 395, 763-770. [CrossRef]

34. Unger, T.J.; Calderon, G.A.; Bradley, L.C.; Sena-Esteves, M.; Rios, M. Selective Deletion of Bdnf in the Ventromedial and Dorsomedial Hypothalamus of Adult Mice Results in Hyperphagic Behavior and Obesity. J. Neurosci. 2007, $27,14265-14274$. [CrossRef] [PubMed]

35. Komori, T.; Morikawa, Y.; Nanjo, K.; Senba, E. Induction of Brain-Derived Neurotrophic Factor by Leptin in the Ventromedial Hypothalamus. Neuroscience 2006, 139, 1107-1115. [CrossRef] [PubMed]

36. Xu, B.; Goulding, E.H.; Zang, K.; Cepoi, D.; Cone, R.D.; Jones, K.R.; Tecott, L.H.; Reichardt, L.F. Brain-Derived Neurotrophic Factor Regulates Energy Balance Downstream of Melanocortin-4 Receptor. Nat. Neurosci. 2003, 6, 736-742. [CrossRef] [PubMed]

37. Levin, B.E. Neurotrophism and Energy Homeostasis: Perfect Together. Am. J. Physiol. Regul. Integr. Comp. Physiol. 2007, 293, R988-R991. [CrossRef]

38. Bariohay, B.; Lebrun, B.; Moyse, E.; Jean, A. Brain-Derived Neurotrophic Factor Plays a Role as an Anorexigenic Factor in the Dorsal Vagal Complex. Endocrinology 2005, 146, 5612-5620. [CrossRef]

39. Bariohay, B.; Roux, J.; Tardivel, C.; Trouslard, J.; Jean, A.; Lebrun, B. Brain-Derived Neurotrophic Factor/Tropomyosin-Related Kinase Receptor Type B Signaling Is a Downstream Effector of the Brainstem Melanocortin System in Food Intake Control. Endocrinology 2009, 150, 2646-2653. [CrossRef]

40. Spaeth, A.M.; Kanoski, S.E.; Hayes, M.R.; Grill, H.J. TrkB Receptor Signaling in the Nucleus Tractus Solitarius Mediates the Food Intake-Suppressive Effects of Hindbrain BDNF and Leptin. Am. J. Physiol. Endocrinol. Metab. 2012, 302, E1252-E1260. [CrossRef]

41. Wang, C.; Bomberg, E.; Billington, C.; Levine, A.; Kotz, C.M. Brain-Derived Neurotrophic Factor in the Hypothalamic Paraventricular Nucleus Increases Energy Expenditure by Elevating Metabolic Rate. Am. J. Physiol. Regul Integr. Comp. Physiol. 2007, 293, R992-R1002. [CrossRef]

42. Wang, C.; Bomberg, E.; Billington, C.; Levine, A.; Kotz, C.M. Brain-Derived Neurotrophic Factor in the Hypothalamic Paraventricular Nucleus Reduces Energy Intake. Am. J. Physiol. Regul Integr. Comp. Physiol. 2007, 293, R1003-R1012. [CrossRef] [PubMed]

43. An, J.J.; Liao, G.-Y.; Kinney, C.E.; Sahibzada, N.; Xu, B. Discrete BDNF Neurons in the Paraventricular Hypothalamus Control Feeding and Energy Expenditure. Cell Metab. 2015, 22, 175-188. [CrossRef] [PubMed]

44. An, J.J.; Kinney, C.E.; Tan, J.-W.; Liao, G.-Y.; Kremer, E.J.; Xu, B. TrkB-Expressing Paraventricular Hypothalamic Neurons Suppress Appetite through Multiple Neurocircuits. Nat. Commun. 2020, 11, 1729. [CrossRef]

45. Houtz, J.; Liao, G.-Y.; An, J.J.; Xu, B. Discrete TrkB-Expressing Neurons of the Dorsomedial Hypothalamus Regulate Feeding and Thermogenesis. Proc. Natl. Acad. Sci. USA 2021, 118, e2017218118. [CrossRef] [PubMed]

46. Westerterp, K.R. Control of Energy Expenditure in Humans. Eur. J. Clin. Nutr. 2017, 71, 340-344. [CrossRef]

47. You, H.; Chu, P.; Guo, W.; Lu, B. A Subpopulation of Bdnf-E1-Expressing Glutamatergic Neurons in the Lateral Hypothalamus Critical for Thermogenesis Control. Mol. Metab. 2020, 31, 109-123. [CrossRef] [PubMed]

48. Tsuchida, A.; Nonomura, T.; Ono-Kishino, M.; Nakagawa, T.; Taiji, M.; Noguchi, H. Acute Effects of Brain-Derived Neurotrophic Factor on Energy Expenditure in Obese Diabetic Mice. Int. J. Obes. Relat. Metab. Disord. 2001, 25, 1286-1293. [CrossRef]

49. Cao, L.; Choi, E.Y.; Liu, X.; Martin, A.; Wang, C.; Xu, X.; During, M.J. White to Brown Fat Phenotypic Switch Induced by Genetic and Environmental Activation of a Hypothalamic-Adipocyte Axis. Cell Metab. 2011, 14, 324-338. [CrossRef] [PubMed]

50. Wang, C.; Bomberg, E.; Billington, C.J.; Levine, A.S.; Kotz, C.M. Brain-Derived Neurotrophic Factor (BDNF) in the Hypothalamic Ventromedial Nucleus Increases Energy Expenditure. Brain Res. 2010, 1336, 66-77. [CrossRef]

51. Zhou, Q.; Bian, H.; Wang, M.; Ni, X.; Yang, W.Z.; Sun, H.; Shen, W.L. Dorsomedial Hypothalamic BDNF Neurons Integrate Thermal Afferent Signals to Control Energy Expenditure. bioRxiv 2021. [CrossRef]

52. Saito, M.; Okamatsu-Ogura, Y.; Matsushita, M.; Watanabe, K.; Yoneshiro, T.; Nio-Kobayashi, J.; Iwanaga, T.; Miyagawa, M.; Kameya, T.; Nakada, K.; et al. High Incidence of Metabolically Active Brown Adipose Tissue in Healthy Adult Humans: Effects of Cold Exposure and Adiposity. Diabetes 2009, 58, 1526-1531. [CrossRef] [PubMed]

53. Bechara, R.G.; Lyne, R.; Kelly, Á.M. BDNF-Stimulated Intracellular Signalling Mechanisms Underlie Exercise-Induced Improvement in Spatial Memory in the Male Wistar Rat. Behav. Brain Res. 2014, 275, 297-306. [CrossRef] [PubMed]

54. Szuhany, K.L.; Bugatti, M.; Otto, M.W. A Meta-Analytic Review of the Effects of Exercise on Brain-Derived Neurotrophic Factor. J. Psychiatr. Res. 2015, 60, 56-64. [CrossRef]

55. Cotman, C.W.; Berchtold, N.C.; Christie, L.-A. Exercise Builds Brain Health: Key Roles of Growth Factor Cascades and Inflammation. Trends Neurosci. 2007, 30, 464-472. [CrossRef]

56. Matthews, V.B.; Aström, M.-B.; Chan, M.H.S.; Bruce, C.R.; Krabbe, K.S.; Prelovsek, O.; Akerström, T.; Yfanti, C.; Broholm, C.; Mortensen, O.H.; et al. Brain-Derived Neurotrophic Factor Is Produced by Skeletal Muscle Cells in Response to Contraction and Enhances Fat Oxidation via Activation of AMP-Activated Protein Kinase. Diabetologia 2009, 52, 1409-1418. [CrossRef] [PubMed]

57. Fulgenzi, G.; Hong, Z.; Tomassoni-Ardori, F.; Barella, L.F.; Becker, J.; Barrick, C.; Swing, D.; Yanpallewar, S.; Croix, B.S.; Wess, J.; et al. Novel Metabolic Role for BDNF in Pancreatic $\beta$-Cell Insulin Secretion. Nat. Commun. 2020, 11, 1950. [CrossRef]

58. Fahimi, A.; Baktir, M.A.; Moghadam, S.; Mojabi, F.S.; Sumanth, K.; McNerney, M.W.; Ponnusamy, R.; Salehi, A. Physical Exercise Induces Structural Alterations in the Hippocampal Astrocytes: Exploring the Role of BDNF-TrkB Signaling. Brain Struct. Funct. 2017, 222, 1797-1808. [CrossRef]

59. Kim, K.; Sung, Y.-H.; Seo, J.-H.; Lee, S.-W.; Lim, B.-V.; Lee, C.-Y.; Chung, Y.-R. Effects of Treadmill Exercise-Intensity on Short-Term Memory in the Rats Born of the Lipopolysaccharide-Exposed Maternal Rats. J. Exerc. Rehabil. 2015, 11, 296-302. [CrossRef] 
60. LeMaster, A.M.; Krimm, R.F.; Davis, B.M.; Noel, T.; Forbes, M.E.; Johnson, J.E.; Albers, K.M. Overexpression of Brain-Derived Neurotrophic Factor Enhances Sensory Innervation and Selectively Increases Neuron Number. J. Neurosci. 1999, 19, 5919-5931. [CrossRef]

61. Johnson, R.A.; Rhodes, J.S.; Jeffrey, S.L.; Garland, T.; Mitchell, G.S. Hippocampal Brain-Derived Neurotrophic Factor but Not Neurotrophin-3 Increases More in Mice Selected for Increased Voluntary Wheel Running. Neuroscience 2003, 121, 1-7. [CrossRef]

62. Vaynman, S.; Ying, Z.; Gomez-Pinilla, F. Hippocampal BDNF Mediates the Efficacy of Exercise on Synaptic Plasticity and Cognition. Eur. J. Neurosci. 2004, 20, 2580-2590. [CrossRef]

63. Rasmussen, P.; Brassard, P.; Adser, H.; Pedersen, M.V.; Leick, L.; Hart, E.; Secher, N.H.; Pedersen, B.K.; Pilegaard, H. Evidence for a Release of Brain-Derived Neurotrophic Factor from the Brain during Exercise. Exp. Physiol. 2009, 94, 1062-1069. [CrossRef]

64. Erickson, K.I.; Voss, M.W.; Prakash, R.S.; Basak, C.; Szabo, A.; Chaddock, L.; Kim, J.S.; Heo, S.; Alves, H.; White, S.M.; et al. Exercise Training Increases Size of Hippocampus and Improves Memory. Proc. Natl. Acad. Sci. USA 2011, 108, $3017-3022$. [CrossRef] [PubMed]

65. Neeper, S.A.; Gómez-Pinilla, F.; Choi, J.; Cotman, C. Exercise and Brain Neurotrophins. Nature 1995, 373, 109. [CrossRef]

66. Wang, R.; Holsinger, R.M.D. Exercise-Induced Brain-Derived Neurotrophic Factor Expression: Therapeutic Implications for Alzheimer's Dementia. Ageing Res. Rev. 2018, 48, 109-121. [CrossRef] [PubMed]

67. Yang, X.; Brobst, D.; Chan, W.S.; Tse, M.C.L.; Herlea-Pana, O.; Ahuja, P.; Bi, X.; Zaw, A.M.; Kwong, Z.S.W.; Jia, W.-H.; et al. Muscle-Generated BDNF Is a Sexually Dimorphic Myokine That Controls Metabolic Flexibility. Sci. Signal. 2019, 12, eaau1468. [CrossRef] [PubMed]

68. Lee, J.H.; Jun, H.-S. Role of Myokines in Regulating Skeletal Muscle Mass and Function. Front. Physiol. 2019, 10, 42. [CrossRef] [PubMed]

69. Mousavi, K.; Jasmin, B.J. BDNF Is Expressed in Skeletal Muscle Satellite Cells and Inhibits Myogenic Differentiation. J. Neurosci. 2006, 26, 5739-5749. [CrossRef] [PubMed]

70. Clow, C.; Jasmin, B.J. Brain-Derived Neurotrophic Factor Regulates Satellite Cell Differentiation and Skeltal Muscle Regeneration. Mol. Biol. Cell 2010, 21, 2182-2190. [CrossRef] [PubMed]

71. Omura, T.; Sano, M.; Omura, K.; Hasegawa, T.; Doi, M.; Sawada, T.; Nagano, A. Different Expressions of BDNF, NT3, and NT4 in Muscle and Nerve after Various Types of Peripheral Nerve Injuries. J. Peripher. Nerv. Syst. 2005, 10, 293-300. [CrossRef] [PubMed]

72. Mousavi, K.; Parry, D.J.; Jasmin, B.J. BDNF Rescues Myosin Heavy Chain IIB Muscle Fibers after Neonatal Nerve Injury. Am. J. Physiol. Cell Physiol. 2004, 287, C22-C29. [CrossRef]

73. Chevrel, G.; Hohlfeld, R.; Sendtner, M. The Role of Neurotrophins in Muscle under Physiological and Pathological Conditions. Muscle Nerve 2006, 33, 462-476. [CrossRef] [PubMed]

74. Delezie, J.; Weihrauch, M.; Maier, G.; Tejero, R.; Ham, D.J.; Gill, J.F.; Karrer-Cardel, B.; Rüegg, M.A.; Tabares, L.; Handschin, C. BDNF Is a Mediator of Glycolytic Fiber-Type Specification in Mouse Skeletal Muscle. Proc. Natl. Acad. Sci. USA 2019, 116, 16111-16120. [CrossRef]

75. Yamanaka, M.; Tsuchida, A.; Nakagawa, T.; Nonomura, T.; Ono-Kishino, M.; Sugaru, E.; Noguchi, H.; Taiji, M. Brain-Derived Neurotrophic Factor Enhances Glucose Utilization in Peripheral Tissues of Diabetic Mice. Diabetes Obes. Metab. 2007, 9, 59-64. [CrossRef]

76. Gomez-Pinilla, F.; Vaynman, S.; Ying, Z. Brain-Derived Neurotrophic Factor Functions as a Metabotrophin to Mediate the Effects of Exercise on Cognition. Eur. J. Neurosci. 2008, 28, 2278-2287. [CrossRef] [PubMed]

77. Mattson, M.P.; Moehl, K.; Ghena, N.; Schmaedick, M.; Cheng, A. Intermittent Metabolic Switching, Neuroplasticity and Brain Health. Nat. Rev. Neurosci. 2018, 19, 63-80. [CrossRef] [PubMed]

78. Lezi, E.; Burns, J.M.; Swerdlow, R.H. Effect of High-Intensity Exercise on Aged Mouse Brain Mitochondria, Neurogenesis, and Inflammation. Neurobiol. Aging 2014, 35, 2574-2583. [CrossRef]

79. Khabour, O.F.; Alzoubi, K.H.; Alomari, M.A.; Alzubi, M.A. Changes in Spatial Memory and BDNF Expression to Simultaneous Dietary Restriction and Forced Exercise. Brain Res. Bull. 2013, 90, 19-24. [CrossRef]

80. Kops, G.J.P.L.; Dansen, T.B.; Polderman, P.E.; Saarloos, I.; Wirtz, K.W.A.; Coffer, P.J.; Huang, T.-T.; Bos, J.L.; Medema, R.H.; Burgering, B.M.T. Forkhead Transcription Factor FOXO3a Protects Quiescent Cells from Oxidative Stress. Nature 2002, 419, 316-321. [CrossRef]

81. Cheng, A.; Wan, R.; Yang, J.-L.; Kamimura, N.; Son, T.G.; Ouyang, X.; Luo, Y.; Okun, E.; Mattson, M.P. Involvement of PGC-1 $\alpha$ in the Formation and Maintenance of Neuronal Dendritic Spines. Nat. Commun. 2012, 3, 1250. [CrossRef] [PubMed]

82. Wrann, C.D.; White, J.P.; Salogiannnis, J.; Laznik-Bogoslavski, D.; Wu, J.; Ma, D.; Lin, J.D.; Greenberg, M.E.; Spiegelman, B.M. Exercise Induces Hippocampal BDNF through a PGC-1 $\alpha$ /FNDC5 Pathway. Cell Metab. 2013, 18, 649-659. [CrossRef] [PubMed]

83. Boström, P.; Wu, J.; Jedrychowski, M.P.; Korde, A.; Ye, L.; Lo, J.C.; Rasbach, K.A.; Boström, E.A.; Choi, J.H.; Long, J.Z.; et al. A PGC1- $\alpha$-Dependent Myokine That Drives Brown-Fat-like Development of White Fat and Thermogenesis. Nature 2012, 481, 463-468. [CrossRef] [PubMed]

84. Gusdon, A.M.; Callio, J.; Distefano, G.; O’Doherty, R.M.; Goodpaster, B.H.; Coen, P.M.; Chu, C.T. Exercise Increases Mitochondrial Complex I Activity and DRP1 Expression in the Brains of Aged Mice. Exp. Gerontol. 2017, 90, 1-13. [CrossRef]

85. Markham, A.; Cameron, I.; Franklin, P.; Spedding, M. BDNF Increases Rat Brain Mitochondrial Respiratory Coupling at Complex I, but Not Complex II. Eur. J. Neurosci. 2004, 20, 1189-1196. [CrossRef] 
86. Markham, A.; Cameron, I.; Bains, R.; Franklin, P.; Kiss, J.P.; Schwendimann, L.; Gressens, P.; Spedding, M. Brain-Derived Neurotrophic Factor-Mediated Effects on Mitochondrial Respiratory Coupling and Neuroprotection Share the Same Molecular Signalling Pathways. Eur. J. Neurosci. 2012, 35, 366-374. [CrossRef]

87. Zheng, W.-H.; Quirion, R. Comparative Signaling Pathways of Insulin-like Growth Factor-1 and Brain-Derived Neurotrophic Factor in Hippocampal Neurons and the Role of the PI3 Kinase Pathway in Cell Survival. J. Neurochem. 2004, 89, 844-852. [CrossRef] [PubMed]

88. Kojima, M.; Hosoda, H.; Date, Y.; Nakazato, M.; Matsuo, H.; Kangawa, K. Ghrelin Is a Growth-Hormone-Releasing Acylated Peptide from Stomach. Nature 1999, 402, 656-660. [CrossRef]

89. Ames, A. CNS Energy Metabolism as Related to Function. Brain Res. Brain Res. Rev. 2000, 34, 42-68. [CrossRef]

90. Burkhalter, J.; Fiumelli, H.; Allaman, I.; Chatton, J.-Y.; Martin, J.-L. Brain-Derived Neurotrophic Factor Stimulates Energy Metabolism in Developing Cortical Neurons. J. Neurosci. 2003, 23, 8212-8220. [CrossRef]

91. Marosi, K.; Kim, S.W.; Moehl, K.; Scheibye-Knudsen, M.; Cheng, A.; Cutler, R.; Camandola, S.; Mattson, M.P. 3-Hydroxybutyrate Regulates Energy Metabolism and Induces BDNF Expression in Cerebral Cortical Neurons. J. Neurochem. 2016, 139, 769-781. [CrossRef]

92. Tsuchida, A.; Nakagawa, T.; Itakura, Y.; Ichihara, J.; Ogawa, W.; Kasuga, M.; Taiji, M.; Noguchi, H. The Effects of Brain-Derived Neurotrophic Factor on Insulin Signal Transduction in the Liver of Diabetic Mice. Diabetologia 2001, 44, 555-566. [CrossRef]

93. Hanyu, O.; Yamatani, K.; Ikarashi, T.; Soda, S.; Maruyama, S.; Kamimura, T.; Kaneko, S.; Hirayama, S.; Suzuki, K.; Nakagawa, O.; et al. Brain-Derived Neurotrophic Factor Modulates Glucagon Secretion from Pancreatic Alpha Cells: Its Contribution to Glucose Metabolism. Diabetes Obes. Metab. 2003, 5, 27-37. [CrossRef]

94. Yamanaka, M.; Itakura, Y.; Inoue, T.; Tsuchida, A.; Nakagawa, T.; Noguchi, H.; Taiji, M. Protective Effect of Brain-Derived Neurotrophic Factor on Pancreatic Islets in Obese Diabetic Mice. Metabolism 2006, 55, 1286-1292. [CrossRef]

95. Gotoh, K.; Masaki, T.; Chiba, S.; Ando, H.; Fujiwara, K.; Shimasaki, T.; Mitsutomi, K.; Katsuragi, I.; Kakuma, T.; Sakata, T.; et al. Hypothalamic Brain-Derived Neurotrophic Factor Regulates Glucagon Secretion Mediated by Pancreatic Efferent Nerves. J. Neuroendocr. 2013, 25, 302-311. [CrossRef]

96. Hausman, G.J.; Poulos, S.P.; Richardson, R.L.; Barb, C.R.; Andacht, T.; Kirk, H.C.; Mynatt, R.L. Secreted Proteins and Genes in Fetal and Neonatal Pig Adipose Tissue and Stromal-Vascular Cells. J. Anim. Sci. 2006, 84, 1666-1681. [CrossRef] [PubMed]

97. Bernhard, F.; Landgraf, K.; Klöting, N.; Berthold, A.; Büttner, P.; Friebe, D.; Kiess, W.; Kovacs, P.; Blüher, M.; Körner, A. Functional Relevance of Genes Implicated by Obesity Genome-Wide Association Study Signals for Human Adipocyte Biology. Diabetologia 2013, 56, 311-322. [CrossRef]

98. Nakagomi, A.; Okada, S.; Yokoyama, M.; Yoshida, Y.; Shimizu, I.; Miki, T.; Kobayashi, Y.; Minamino, T. Role of the Central Nervous System and Adipose Tissue BDNF/TrkB Axes in Metabolic Regulation. NPJ Aging Mech. Dis. 2015, 1, 15009. [CrossRef] [PubMed]

99. Zhu, Q.; Liu, X.; Glazier, B.J.; Krolick, K.N.; Yang, S.; He, J.; Lo, C.C.; Shi, H. Differential Sympathetic Activation of Adipose Tissues by Brain-Derived Neurotrophic Factor. Biomolecules 2019, 9, 452. [CrossRef] [PubMed]

100. Chaldakov, G.N.; Tonchev, A.B.; Aloe, L. NGF and BDNF: From Nerves to Adipose Tissue, from Neurokines to Metabokines. Riv. Psichiatr. 2009, 44, 79-87.

101. Inamura, N.; Nawa, H.; Takei, N. Enhancement of Translation Elongation in Neurons by Brain-Derived Neurotrophic Factor: Implications for Mammalian Target of Rapamycin Signaling. J. Neurochem. 2005, 95, 1438-1445. [CrossRef]

102. Dash, P.K.; Orsi, S.A.; Moore, A.N. Spatial Memory Formation and Memory-Enhancing Effect of Glucose Involves Activation of the Tuberous Sclerosis Complex-Mammalian Target of Rapamycin Pathway. J. Neurosci. 2006, 26, 8048-8056. [CrossRef]

103. Dennis, P.B.; Jaeschke, A.; Saitoh, M.; Fowler, B.; Kozma, S.C.; Thomas, G. Mammalian TOR: A Homeostatic ATP Sensor. Science 2001, 294, 1102-1105. [CrossRef]

104. Lage, R.; Diéguez, C.; Vidal-Puig, A.; López, M. AMPK: A Metabolic Gauge Regulating Whole-Body Energy Homeostasis. Trends Mol. Med. 2008, 14, 539-549. [CrossRef]

105. Pedersen, B.K.; Pedersen, M.; Krabbe, K.S.; Bruunsgaard, H.; Matthews, V.B.; Febbraio, M.A. Role of Exercise-Induced BrainDerived Neurotrophic Factor Production in the Regulation of Energy Homeostasis in Mammals. Exp. Physiol. 2009, 94, 1153-1160. [CrossRef] [PubMed]

106. Genzer, Y.; Chapnik, N.; Froy, O. Effect of Brain-Derived Neurotrophic Factor (BDNF) on Hepatocyte Metabolism. Int. J. Biochem. Cell Biol. 2017, 88, 69-74. [CrossRef]

107. Durany, N.; Michel, T.; Kurt, J.; Cruz-Sánchez, F.F.; Cervás-Navarro, J.; Riederer, P. Brain-Derived Neurotrophic Factor and Neurotrophin-3 Levels in Alzheimer's Disease Brains. Int. J. Dev. Neurosci. 2000, 18, 807-813. [CrossRef]

108. Hock, C.; Heese, K.; Hulette, C.; Rosenberg, C.; Otten, U. Region-Specific Neurotrophin Imbalances in Alzheimer Disease: Decreased Levels of Brain-Derived Neurotrophic Factor and Increased Levels of Nerve Growth Factor in Hippocampus and Cortical Areas. Arch. Neurol. 2000, 57, 846-851. [CrossRef] [PubMed]

109. Phillips, H.S.; Hains, J.M.; Armanini, M.; Laramee, G.R.; Johnson, S.A.; Winslow, J.W. BDNF MRNA Is Decreased in the Hippocampus of Individuals with Alzheimer's Disease. Neuron 1991, 7, 695-702. [CrossRef]

110. Murer, M.G.; Yan, Q.; Raisman-Vozari, R. Brain-Derived Neurotrophic Factor in the Control Human Brain, and in Alzheimer's Disease and Parkinson's Disease. Prog. Neurobiol. 2001, 63, 71-124. [CrossRef] 
111. Tapia-Arancibia, L.; Aliaga, E.; Silhol, M.; Arancibia, S. New Insights into Brain BDNF Function in Normal Aging and Alzheimer Disease. Brain Res. Rev. 2008, 59, 201-220. [CrossRef] [PubMed]

112. Murer, M.G.; Boissiere, F.; Yan, Q.; Hunot, S.; Villares, J.; Faucheux, B.; Agid, Y.; Hirsch, E.; Raisman-Vozari, R. An Immunohistochemical Study of the Distribution of Brain-Derived Neurotrophic Factor in the Adult Human Brain, with Particular Reference to Alzheimer's Disease. Neuroscience 1999, 88, 1015-1032. [CrossRef]

113. Narisawa-Saito, M.; Wakabayashi, K.; Tsuji, S.; Takahashi, H.; Nawa, H. Regional Specificity of Alterations in NGF, BDNF and NT-3 Levels in Alzheimer's Disease. Neuroreport 1996, 7, 2925-2928. [CrossRef] [PubMed]

114. Nagahara, A.H.; Merrill, D.A.; Coppola, G.; Tsukada, S.; Schroeder, B.E.; Shaked, G.M.; Wang, L.; Blesch, A.; Kim, A.; Conner, J.M.; et al. Neuroprotective Effects of Brain-Derived Neurotrophic Factor in Rodent and Primate Models of Alzheimer's Disease. Nat. Med. 2009, 15, 331-337. [CrossRef]

115. Chauhan, N.B.; Siegel, G.J.; Lee, J.M. Depletion of Glial Cell Line-Derived Neurotrophic Factor in Substantia Nigra Neurons of Parkinson's Disease Brain. J. Chem. Neuroanat. 2001, 21, 277-288. [CrossRef]

116. Howells, D.W.; Porritt, M.J.; Wong, J.Y.; Batchelor, P.E.; Kalnins, R.; Hughes, A.J.; Donnan, G.A. Reduced BDNF MRNA Expression in the Parkinson's Disease Substantia Nigra. Exp. Neurol. 2000, 166, 127-135. [CrossRef] [PubMed]

117. Porritt, M.J.; Batchelor, P.E.; Howells, D.W. Inhibiting BDNF Expression by Antisense Oligonucleotide Infusion Causes Loss of Nigral Dopaminergic Neurons. Exp. Neurol. 2005, 192, 226-234. [CrossRef]

118. Baquet, Z.C.; Bickford, P.C.; Jones, K.R. Brain-Derived Neurotrophic Factor Is Required for the Establishment of the Proper Number of Dopaminergic Neurons in the Substantia Nigra Pars Compacta. J. Neurosci. 2005, 25, 6251-6259. [CrossRef]

119. Kohno, R.; Sawada, H.; Kawamoto, Y.; Uemura, K.; Shibasaki, H.; Shimohama, S. BDNF Is Induced by Wild-Type Alpha-Synuclein but Not by the Two Mutants, A30P or A53T, in Glioma Cell Line. Biochem. Biophys. Res. Commun. 2004, 318, 113-118. [CrossRef]

120. Zuccato, C.; Cattaneo, E. Brain-Derived Neurotrophic Factor in Neurodegenerative Diseases. Nat. Rev. Neurol. 2009, 5, 311-322. [CrossRef]

121. Zuccato, C.; Cattaneo, E. Role of Brain-Derived Neurotrophic Factor in Huntington's Disease. Prog. Neurobiol. 2007, 81, 294-330. [CrossRef] [PubMed]

122. Zuccato, C.; Marullo, M.; Conforti, P.; MacDonald, M.E.; Tartari, M.; Cattaneo, E. Systematic Assessment of BDNF and Its Receptor Levels in Human Cortices Affected by Huntington's Disease. Brain Pathol. 2008, 18, 225-238. [CrossRef] [PubMed]

123. Zuccato, C.; Ciammola, A.; Rigamonti, D.; Leavitt, B.R.; Goffredo, D.; Conti, L.; MacDonald, M.E.; Friedlander, R.M.; Silani, V.; Hayden, M.R.; et al. Loss of Huntingtin-Mediated BDNF Gene Transcription in Huntington's Disease. Science 2001, 293, 493-498. [CrossRef]

124. Zuccato, C.; Belyaev, N.; Conforti, P.; Ooi, L.; Tartari, M.; Papadimou, E.; MacDonald, M.; Fossale, E.; Zeitlin, S.; Buckley, N.; et al. Widespread Disruption of Repressor Element-1 Silencing Transcription Factor/Neuron-Restrictive Silencer Factor Occupancy at Its Target Genes in Huntington's Disease. J. Neurosci. 2007, 27, 6972-6983. [CrossRef] [PubMed]

125. Gauthier, L.R.; Charrin, B.C.; Borrell-Pagès, M.; Dompierre, J.P.; Rangone, H.; Cordelières, F.P.; De Mey, J.; MacDonald, M.E.; Lessmann, V.; Humbert, S.; et al. Huntingtin Controls Neurotrophic Support and Survival of Neurons by Enhancing BDNF Vesicular Transport along Microtubules. Cell 2004, 118, 127-138. [CrossRef]

126. Mitsumoto, H.; Ikeda, K.; Klinkosz, B.; Cedarbaum, J.M.; Wong, V.; Lindsay, R.M. Arrest of Motor Neuron Disease in Wobbler Mice Cotreated with CNTF and BDNF. Science 1994, 265, 1107-1110. [CrossRef]

127. Korkmaz, O.T.; Aytan, N.; Carreras, I.; Choi, J.-K.; Kowall, N.W.; Jenkins, B.G.; Dedeoglu, A. 7,8-Dihydroxyflavone Improves Motor Performance and Enhances Lower Motor Neuronal Survival in a Mouse Model of Amyotrophic Lateral Sclerosis. Neurosci. Lett. 2014, 566, 286-291. [CrossRef]

128. Shirayama, Y.; Chen, A.C.-H.; Nakagawa, S.; Russell, D.S.; Duman, R.S. Brain-Derived Neurotrophic Factor Produces Antidepressant Effects in Behavioral Models of Depression. J. Neurosci. 2002, 22, 3251-3261. [CrossRef]

129. Hashimoto, T.; Bergen, S.E.; Nguyen, Q.L.; Xu, B.; Monteggia, L.M.; Pierri, J.N.; Sun, Z.; Sampson, A.R.; Lewis, D.A. Relationship of Brain-Derived Neurotrophic Factor and Its Receptor TrkB to Altered Inhibitory Prefrontal Circuitry in Schizophrenia. J. Neurosci. 2005, 25, 372-383. [CrossRef]

130. Weickert, C.S.; Hyde, T.M.; Lipska, B.K.; Herman, M.M.; Weinberger, D.R.; Kleinman, J.E. Reduced Brain-Derived Neurotrophic Factor in Prefrontal Cortex of Patients with Schizophrenia. Mol. Psychiatry 2003, 8, 592-610. [CrossRef]

131. Wong, J.; Hyde, T.M.; Cassano, H.L.; Deep-Soboslay, A.; Kleinman, J.E.; Weickert, C.S. Promoter Specific Alterations of BrainDerived Neurotrophic Factor MRNA in Schizophrenia. Neuroscience 2010, 169, 1071-1084. [CrossRef]

132. A Controlled Trial of Recombinant Methionyl Human BDNF in ALS: The BDNF Study Group (Phase III). Neurology 1999, 52, 1427-1433. [CrossRef]

133. Ochs, G.; Penn, R.D.; York, M.; Giess, R.; Beck, M.; Tonn, J.; Haigh, J.; Malta, E.; Traub, M.; Sendtner, M.; et al. A Phase I/II Trial of Recombinant Methionyl Human Brain Derived Neurotrophic Factor Administered by Intrathecal Infusion to Patients with Amyotrophic Lateral Sclerosis. Amyotroph. Lateral Scler Other Motor Neuron Disord. 2000, 1, 201-206. [CrossRef]

134. Hamer, M.; Chida, Y. Physical Activity and Risk of Neurodegenerative Disease: A Systematic Review of Prospective Evidence. Psychol. Med. 2009, 39, 3-11. [CrossRef] [PubMed]

135. Miranda, M.; Morici, J.F.; Zanoni, M.B.; Bekinschtein, P. Brain-Derived Neurotrophic Factor: A Key Molecule for Memory in the Healthy and the Pathological Brain. Front. Cell. Neurosci. 2019, 13, 363. [CrossRef] 
136. Merrill, D.A.; Siddarth, P.; Raji, C.A.; Emerson, N.D.; Rueda, F.; Ercoli, L.M.; Miller, K.J.; Lavretsky, H.; Harris, L.M.; Burggren, A.C.; et al. Modifiable Risk Factors and Brain Positron Emission Tomography Measures of Amyloid and Tau in Nondemented Adults with Memory Complaints. Am. J. Geriatr. Psychiatry 2016, 24, 729-737. [CrossRef]

137. Mattson, M.P. Interventions That Improve Body and Brain Bioenergetics for Parkinson's Disease Risk Reduction and Therapy. J. Parkinsons. Dis. 2014, 4, 1-13. [CrossRef] [PubMed]

138. Monteiro-Junior, R.S.; Cevada, T.; Oliveira, B.R.R.; Lattari, E.; Portugal, E.M.M.; Carvalho, A.; Deslandes, A.C. We Need to Move More: Neurobiological Hypotheses of Physical Exercise as a Treatment for Parkinson's Disease. Med. Hypotheses 2015, 85, 537-541. [CrossRef] [PubMed]

139. Di Liegro, C.M.; Schiera, G.; Proia, P.; Di Liegro, I. Physical Activity and Brain Health. Genes (Basel) 2019, 10, 720. [CrossRef]

140. Pickrell, A.M.; Youle, R.J. The Roles of PINK1, Parkin, and Mitochondrial Fidelity in Parkinson's Disease. Neuron 2015, 85, 257-273. [CrossRef] [PubMed]

141. Mattson, M.P. Evolutionary Aspects of Human Exercise-Born to Run Purposefully. Ageing Res. Rev. 2012, 11, 347-352. [CrossRef]

142. Tang, B.L. Glucose, Glycolysis, and Neurodegenerative Diseases. J. Cell. Physiol. 2020, 235, 7653-7662. [CrossRef] [PubMed]

143. Giuffrida, M.L.; Tomasello, M.F.; Pandini, G.; Caraci, F.; Battaglia, G.; Busceti, C.; Di Pietro, P.; Pappalardo, G.; Attanasio, F.; Chiechio, S.; et al. Monomeric SS-Amyloid Interacts with Type-1 Insulin-like Growth Factor Receptors to Provide Energy Supply to Neurons. Front. Cell Neurosci. 2015, 9, 297. [CrossRef]

144. Zimbone, S.; Monaco, I.; Gianì, F.; Pandini, G.; Copani, A.G.; Giuffrida, M.L.; Rizzarelli, E. Amyloid Beta Monomers Regulate Cyclic Adenosine Monophosphate Response Element Binding Protein Functions by Activating Type-1 Insulin-like Growth Factor Receptors in Neuronal Cells. Aging Cell 2018, 17, e12684. [CrossRef] [PubMed]

145. Santangelo, R.; Giuffrida, M.L.; Satriano, C.; Tomasello, M.F.; Zimbone, S.; Copani, A. $\beta$-Amyloid Monomers Drive up Neuronal Aerobic Glycolysis in Response to Energy Stressors. Aging (Albany NY) 2021, 13, 18033-18050. [CrossRef] [PubMed] 